\title{
Quality of Financial Reporting Choice: Determinants and Economic Consequences
}

\author{
Daniel A. Cohen \\ Department of Accounting and Information Management \\ Kellogg School of Management \\ Northwestern University \\ 2001 Sheridan Road, Evanston IL 60208 \\ Tel: (847) 491-2658 \\ E-mail: $\underline{\text { d-cohen3@kellogg.northwestern.edu }}$
}

This Draft: December 2003

First Draft: March 2003*

I would like to thank the members of my dissertation committee, Robert Korajczyk, Robert Magee, and
especially Thomas Lys (Chair) and Beverly Walther for their valuable comments, guidance and
discussions. Conference participants at the 2003 Accounting Symposium at London Business School,
especially Wayne Landsman (the discussant), Sasson Bar-Yosef, Aiyesha Dey, Tom Fields, Steve
Hillegeist, Nisan Langberg, Xiaohui Liu, Meredith Maher, Lawrence Revsine, and Shyam Sunder all
provided useful suggestions and comments on earlier versions. I am grateful to the Biotechnology Research
Center at the Kellogg School of Management and the Zell Center for Risk Research for financial support.
*An earlier version of this paper was presented at the 2003 London Business School Accounting
Symposium, July 32003 . 


\title{
Quality of Financial Reporting Choice: Determinants and Economic Consequences
}

\begin{abstract}
I investigate the determinants and economic consequences associated with firms' financial reporting choices. Recognizing the endogeneity associated with these choices, I find evidence of a positive association between investors' demands for firm-specific information and financial reporting quality. I also find that higher proprietary costs are associated with a lower quality of financial information. As for the economic consequences, the evidence suggests that firms with high quality financial reporting policies have reduced information asymmetries. However, after accounting for the endogeneity associated with the reporting quality choice, I find no significant evidence that firms choosing to provide financial information of higher quality enjoy a lower cost of equity capital. These results demonstrate the importance of explicitly modeling the endogeneity of financial reporting choices in investigating the associated economic consequences.
\end{abstract}

Key Words: Financial reporting quality, cost of equity capital, proprietary costs, risk factors, endogeneity.

Data Availability: The data used in the study are from public sources identified in the text. 


\section{Introduction}

I investigate the determinants and economic consequences of cross-sectional variation in firms' choices concerning the quality of their financial reporting. While the quality of financial reporting may be judged from a number of perspectives (e.g., earnings persistence, predictability of future performance, earnings variability, the relation between cash, accruals and income), I focus on how reported accounting numbers accurately represent the underlying economic fundamentals of the firm. Specifically, I define high-quality reported earnings as those that are highly associated with future operating cash flows. ${ }^{1}$ This focus is motivated by the objectives of the Financial Accounting Standards Board (FASB), as reflected in its Statement of Financial Concepts No. 1, Objectives of Financial Reporting by Business Enterprises [1978], paragraphs 3739 and $44 .^{2}$

Economic theory suggests that, ceteris paribus, increasing the quality of financial information reduces information asymmetries and hence lowers the cost of capital (e.g., Amihud and Mendelson [1986], Diamond and Verrecchia [1991], Easley and O’Hara [2003], and Glosten and Milgrom [1985]). A firm can reduce information asymmetries between itself and market participants and between informed and uninformed investors by providing information that help investors in their decision making process. Consistent with these theoretical models, empirical studies using indirect measures of disclosure document that a firm's disclosure quality/level is positively associated with capital market valuation benefits (Welker [1995], Healy et al. [1999]), and, in particular, is inversely related to its cost of capital (e.g., Botosan [1997], Botosan and Plumlee [2002]). Using more direct measures of accounting information quality, recent empirical work focuses on the association between earnings quality and the cost of capital (e.g., Barone [2002], Barth and Landsman [2003], Bhattacharya, Daouk and Welker [2003], and Francis et al. [2003a, 2003b]).

However, in spite of the valuation benefits providing high-quality financial information affords, many firms decide against the maximum reporting quality. This

\footnotetext{
${ }^{1}$ This is consistent with the definition of earnings quality in Mikhail et al. [2003]. They define it as: "the extent to which a firm's past earnings are associated with its future operating cash flows.”

${ }^{2}$ Paragraph 37 states: “...[F]inancial reporting should provide information to help present and potential investors and creditors and other users in assessing the amounts, timing, and uncertainty of prospective cash receipts.....Thus, financial reporting should provide information to help investors, creditors, and others assess the amounts, timing, and uncertainty of prospective net cash inflows to the related enterprise." Paragraph 44 states: "[I]nformation about enterprise earnings and its components measured by accrual accounting generally provides a better indication of enterprise performance than information about current cash receipts and payments.”
} 
decision likely reflects the potential costs associated with disseminating high-quality information (see Fields et al. [2001] for a discussion). For instance, high-quality financial information, if it is characterized as proprietary, can result in competitive disadvantages in a firm's product market. Firms are thus likely to consider the potential liabilities of providing high-quality financial reports when choosing an optimal level of informativeness in their financial statements. Such considerations make it difficult to interpret the association of high-quality reporting with capital market valuation benefits documented in prior research.

A significant shortcoming of numerous empirical disclosure studies is the failure to address the endogenous nature of the disclosure quality decision. If researchers do not control for the determinants of disclosure policy, their inferences regarding the economic consequences of disclosure quality may be spurious (Fields et. al [2001], Core [2001]). The research design used in this study specifically addresses these concerns by accounting for the endogenous nature of the financial reporting decision. In particular, this study identifies the factors that determine the variation in financial reporting quality choices and the associated economic consequences.

While economic theory that relates the quality of accounting information and the potential valuation benefits and proprietary costs is compelling, empirical evidence supporting the theory is scarce (see the survey article by Healy and Palepu [2001]). For example, Piotroski [2003] investigates both the proprietary costs and valuation benefits associated with managers' financial reporting decisions. Piotroski focuses only on a specific facet of the overall financial reporting policy, namely the segment reporting choice. My primary objective is to better understand the determinants and consequences of a broader aspect of a firm's financial reporting policy, as evidenced by the quality of financial reporting it chooses.

I find evidence that higher investors' demands for firm-specific information are associated with higher quality of financial reporting. In addition, the results suggest that higher proprietary costs are associated with lower quality of financial information. My findings also indicate that firms with high-quality financial reporting policies have lower information asymmetries (as proxied by bid-ask spreads), lower uncertainty, and lower estimation risk (as reflected in lower analyst forecast dispersion and higher analyst following). However, I do not find evidence that firms choosing to provide high-quality 
financial information necessarily enjoy a lower cost of equity capital. This result conflicts with the results of prior research (e.g., Barone [2002] and Francis et. al [2003a]). ${ }^{3}$ My evidence suggests that the link found in previous research between a firm's quality of accounting information and its cost of capital results from a failure to consider factors determining the quality of financial reporting chosen by the reporting firm. My analysis implies that the information risk associated with the quality of financial reporting does not necessarily constitute an additional risk factor, but rather is a firm-specific uncertainty characteristic. This finding suggests that capital market participants are not likely to price the documented uncertainty as other risk factors, such as beta, size and book-to-market ratios. In other words the information risk associated with financial reporting quality choice is an idiosyncratic risk factor rather than a systematic one priced by investors. ${ }^{4}$

This study contributes to the existing accounting literature in several ways. Its main contribution is that it accounts for the endogenous character of firms' decision about the quality of their financial reporting. I show that the failure to address this endogeneity affects the inferences made and conclusions drawn by previous studies. Next, responding to concerns about certain empirical measures of disclosure quality (e.g. Healy and Palepu [2001]), I introduce a new measure of reporting quality which can be used in more general research settings for broad samples of firms. Finally, this study's findings have important implications for research on the consequences of firms' disclosure policies. The evidence I present suggests that the variation in financial reporting quality depends not only on the benefits firms expect to derive from disclosure, but also on the proprietary costs firms face. Future work on determinants and consequences of financial reporting policies should thus consider both the costs and benefits associated with a reporting policy choice.

\footnotetext{
${ }^{3}$ Recent empirical studies which investigate the association between earnings quality (and other earnings attributes) and the cost of capital treat earnings quality as an exogenous variable (e.g., Barone [2002], Barth and Landsman [2003], and Francis et al. [2003a]). Therefore, these studies ignore any discretionary aspect associated with the choice of the quality of reported earnings. In concurrent work, Francis et al. [2003b] distinguish between non-discretionary and discretionary components of accruals quality and find that the discretionary component has a significantly lower pricing effect on the cost of capital. Moreover, they find that the discretionary accruals component is both smaller and in general less statistically significant than the cost of capital effect of the non-discretionary component. I discuss these results in Section 4.

${ }^{4}$ As a robustness check, I validate my empirical reporting quality measure with an earnings quality measure introduced by Dechow and Dichev [2002]. The tenor and significance of the reported results is unchanged under this alternative specification.
} 
The remainder of the paper is organized as follows. Section 2 provides a literature review and presents the theoretical background on the determinants and consequences associated with financial reporting decisions. Section 3 describes the research design and addresses methodological issues. Section 4 presents the sample selection criteria and discusses the empirical results. Section 5 concludes.

\section{Relation to Prior Research}

Theoretical research investigating the link between disclosure and a firm's cost of capital suggests a negative association between the two. The first stream of research arguing for this association concludes that firms with increased levels of disclosure reduce the cost of capital arising from information asymmetries, either between firms and its stockholders, or between potential traders in the firm's shares. Examples of theoretical work in this area are Copeland and Galai [1983], Glosten and Milgrom [1985], and Diamond and Verrecchia [1991]. Diamond and Verrecchia [1991] suggest that higher disclosure reduces the amount of information revealed by a large trade in a firm's securities, thereby reducing the negative price impact associated with such large trades. In this scenario investors would have relatively large positions in a particular firm's securities. There would be a higher demand for the firm's securities, which would increase the price of the firm's stock, thereby reducing the cost of equity capital.

Empirical work by Amihud and Mendelson [1986] suggests that firms whose stocks have a higher bid-ask spread have a higher cost of equity capital because investors demand compensation for the added transaction costs. The authors contend that firms that provide more private information can reduce the adverse selection component of the bidask spread, and thus reduce their cost of equity capital.

A second stream of research focuses on the link between estimation risk and the cost of capital (e.g., Barry and Brown [1985]). This research suggests that a firm can reduce the estimation risk associated with its payoff distribution by providing more disclosures. If investors price the estimation risk, providing more information will reduce the firm's cost of capital.

In recent work Easley and O’Hara [2003] demonstrate a link between information structure (private versus public information) and the cost of capital. Developing a rational expectations asset pricing model, they argue that more private information increases the risk faced by uninformed investors since better informed investors can shift their 
portfolio weights to adjust for new information. Easley and O'Hara [2003] imply that firms can affect their cost of capital through the precision and quantity of the information they provide investors. ${ }^{5}$

One of the major limitations of empirical studies on corporate disclosures is the difficulty in measuring the quality of disclosure policies (Healy and Palepu [2001]). ${ }^{6}$ Using the Association of Investment Management and Research (hereafter, AIMR) rankings as an indirect measure of disclosure quality, numerous empirical studies examine the association between these measures and firm characteristics and capital market valuation proxies (e.g., Lang and Lundholm [1993], Healy, Hutton, and Palepu [1999], and Welker [1995]). Lang and Lundholm [1993] find a positive association between the AIMR scores and firm size, firm performance, and security issues, and a negative association between the AIMR scores and the correlation between earnings and returns. Welker [1995] finds that firms with higher AIMR scores have lower information asymmetry, as proxied by bid-ask spreads. Healy, Hutton, and Palepu [1999] find that firms with sustained improvements in analysts' ratings of disclosure quality (AIMR scores) show an increase in stock liquidity, analyst following, institutional ownership, and stock performance.

Previous empirical research has documented mixed and limited evidence that disclosure reduces the cost of capital. Botosan [1997] finds that manufacturing firms with a low security analyst following have a negative association between a self-constructed index of disclosure level and the cost of equity capital. In a related empirical study Sengupta [1998] provides evidence that high disclosure ratings (AIMR) are inversely associated with the cost of debt. Botosan and Plumlee [2002] find a negative relation between the annual report disclosure level (as measured by the AIMR ratings) and the cost of capital. Yet they also document that the cost of capital is positively associated with the levels of disclosures in quarterly reports (this finding is contrary to the prediction of the theory). In a different context Leuz and Verrecchia [2000] show that German firms that adopt a high-quality reporting regime by switching to international reporting

\footnotetext{
${ }^{5}$ Easley and O’Hara [2003, pg. 37] claim that “An important implication of our research is that firms can influence their cost of capital by affecting the precision and quantity of information available to investors. This can be accomplished by a firm's selection of its accounting standards, as well as through its corporate disclosure policies."

${ }^{6}$ The difficulty in measuring disclosure quality has led some researchers to focus on management forecasts (e.g., Coller and Yohn [1997], Pownall, Wasley, and Waymire [1993]). Others examine disclosure quality ratings, for example, Lang and Lundholm [1996], Healy, Hutton, and Palepu [1999], and Welker [1995].
} 
standards exhibit lower information asymmetry, as reflected by lower bid-ask spreads and higher trading volume. To summarize, empirical evidence on the relation between disclosures and the cost of capital generally suggests an inverse relation between the cost of capital and disclosures.

A separate but complementary branch of analytical research examines the costs, especially the proprietary ones, associated with disclosure decisions. Models such as Dye [1985b, 1986], Verrecchia [1983, 1990], Darrough and Stoughton [1990], Wagenhofer [1990], and Hayes and Lundholm [1996] argue that, all things being equal, the probability of disclosure decreases as the associated proprietary costs increase. Most of these proprietary costs borne by firms arise from interaction with other parties - the costs of competitive disadvantage from disclosing information to their competitors and regulators, of bargaining disadvantages with both suppliers and consumers, and of litigation that might follow informative disclosure are three such examples. ${ }^{7}$

Wagenhofer [1990] provides a model investigating whether reducing the cost of capital (maximizing market value) offsets the adverse effects of increasing disclosures arising from potential entrants to the firm's product market. Wagenhofer shows that although there is always a full-disclosure equilibrium, partial-disclosure equilibria may also exist. These depend on the information to be disclosed, the level of political costs, and the probability of a competitor entering the product market. Baiman and Verrecchia [1996] present a model that considers both the costs and benefits of disclosure, and show that a trade-off between the two forces exists. A higher level of disclosure reduces the cost of capital, but it also reduces the manager's profits from inside trading.

As Fields et al. [2001] suggest, the empirical evidence presented in studies like Botosan [1997] and Sengupta [1998]) provides interesting insights, but these studies suffer from noteworthy limitations. Most importantly, these studies do not consider the related costs of higher disclosure quality and whether these costs affect the disclosure decision. Firms measure the valuation benefits of providing higher quality earnings against the associated costs. If the proprietary costs outweigh the market valuation benefits, the firm will choose to provide a lower quality of reported earnings, which will

\footnotetext{
${ }^{7}$ Other costs related to disclosure are the costs of developing and presenting financial information. These costs, which are non-proprietary, are of second-order effect. This study focuses only on third party related costs, which are assumed to be proprietary.
} 
be less informative in predicting future performance. This strongly motivates my examination of the costs and benefits associated with disclosure policy choices.

Recognizing the endogenous nature of the financial reporting quality choice, I first model the factors determining this choice. Focusing on these determinants, I test whether firms respond to investors' demands for firm-specific information. Specifically, I examine whether firms with a more highly dispersed investor bases are likely to provide higher quality of financial information in response to investors' information needs. Second, I test whether proprietary cost factors, measured by the level of competition within an industry, growth opportunities, and barriers to entry, affect the reporting decision. As for the economic effects of quality reporting choices, I test whether higher quality reporting is associated with a lower cost of capital. Furthermore, I examine whether lower levels of information asymmetries, lower uncertainty, and estimation risk are associated with higher quality reporting. I test in particular the association between the empirical measure of reporting quality and bid-ask spreads and analyst forecast characteristics (forecast dispersion and the number of analysts following a firm).

\section{Research Design}

Firms’ financial reporting quality decisions are likely to be endogenous. If factors influencing cross-sectional variation in the reporting decision also influence the association between capital market valuation benefits and the quality of the reported accounting information, failing to control for the reporting choice may lead to erroneous inferences (Maddala [1983]). Specifically, an OLS regression of empirical measures for the identified capital markets valuation benefits on firm characteristics and a reporting quality measure would result in inconsistent and biased coefficients. To address this issue, I use a two-stage estimation method (Barnow et al. [1980], Maddala [1983, p.121], and Wooldridge [2002]; see Appendix A for a detailed discussion of the econometric specification). I first discuss my empirical measure of reporting quality and then address the factors determining the reporting choice and its economic consequences.

\subsection{Measurement of Financial Reporting Quality}

Consider the following simple setting: (i) Firms have an objective to maximize their expected value, (ii) At the end of period (t-1), firms release an audited annual earnings report. Aggregate earnings for period (t-1) and its components (cash flow from operations and accruals) are used by various parties (e.g., capital markets participants, customers, 
suppliers, and current and potential competitors) to predict firms' future cash flows at time $\mathrm{t},(\mathrm{t}+1)$, etc.

Analytical models (e.g., Admati and Pleiderer [2000], Baiman and Verrecchia [1996], and Easley and O’Hara [2003]) take the disclosed public information's precision as the measure of its quality. The precision is interpreted as achieving a given level of predictability of expected future cash flows under the flexibility and discretion permitted by GAAP. Thus, the higher the precision, the higher the quality of reported earnings, and the more accurately future cash flows may be predicted.

To measure the level of precision empirically, I focus on the residuals obtained from a regression of future operating cash flows on previous period earnings components. Following prior studies (Fairfield et al. [1996] and Barth et al. [2001]), I partition reported earnings into two main components: cash flow from operations and accruals. I base my measure of financial reporting quality on the residuals obtained from estimating the model specified in equation (1) using ordinary least squares:

$$
\mathrm{CFO}_{\mathrm{i}, \mathrm{t}+1}=\alpha_{0}+\beta_{1} \mathrm{CFO}_{\mathrm{i}, \mathrm{t}}+\beta_{2} \Delta \mathrm{AR}_{\mathrm{i}, \mathrm{t}}+\beta_{3} \Delta \mathrm{INV}_{\mathrm{i}, \mathrm{t}}+\beta_{4} \Delta \mathrm{AP}_{\mathrm{i}, \mathrm{t}}+\beta_{5} \mathrm{DEPR}_{\mathrm{i}, \mathrm{t}}+\beta_{6} \mathrm{OTHER}_{\mathrm{i}, \mathrm{t}}+\varepsilon_{\mathrm{i}, \mathrm{t}+1}
$$

Where:

$\mathrm{CFO}_{\mathrm{i}, \mathrm{t}} \quad$ Cash flow from operations for firm i at year $\mathrm{t}$ (Compustat annual data item \#308) minus the accrual portion of extraordinary items and discontinued operations per the statement of cash flows (Compustat annual data item \#124);

$\Delta \mathrm{AR}_{\mathrm{i}, \mathrm{t}} \quad$ Change in accounts receivable account per the statement of cash flows (Compustat annual data item \#302);

$\Delta \mathrm{INV}_{\mathrm{i}, \mathrm{t}} \quad$ Change in inventory account per the statement of cash flow (Compustat annual data item \#303);

$\triangle \mathrm{AP}_{\mathrm{i}, \mathrm{t}} \quad$ Change in accounts payable and accrued liabilities account per the statement of cash flows (Compustat annual data item \#304);

$\mathrm{DEPR}_{\mathrm{i}, \mathrm{t}} \quad$ Depreciation and Amortization Expense (Compustat annual data item \#125);

OTHER $_{i, t} \quad$ Net of all other accruals, calculated as EARN $-(C F O+\Delta A R+\Delta I N V-$ $\triangle \mathrm{AP}-\mathrm{DEPR})$, where EARN is income before extraordinary items and discontinued operations (Compustat annual data item \#18); ${ }^{8}$

$\varepsilon_{\mathrm{i}, \mathrm{t}+1} \quad$ Error term assumed to have zero mean and constant variance.

\footnotetext{
${ }^{8}$ If Compustat annual data items \#302, \#303, or \#304 are missing, $\triangle \mathrm{AR}, \Delta \mathrm{INV}$, and $\triangle \mathrm{AP}$ are calculated using data from the balance sheet, i.e., accounts receivable (Compustat annual data item \#2), inventory (Compustat annual data item \#3), and accounts payable (Compustat annual data item \#70 plus accrued expenses (Compustat annual data item \#153)).
} 
All variables are deflated by average total assets.

Based on an accrual reporting system, the model estimated in equation (1) suggests that future operating cash flows are predicted by current disaggregated earnings. The evidence presented in Barth et al. [2001] emphasizes the importance of disaggregating accruals, given the different information each major accrual reflects about future cash flows. By focusing on aggregate earnings rather than on the specification identified in equation (1), one places the same weight on each earnings component, and may disregard any information relevant to predicting future cash flows. ${ }^{9}$

In order to obtain the financial reporting quality metric, I estimate equation (1) for each fiscal year t for each two-digit SIC industry code. I focus on the residuals obtained from estimating equation (1). These provide a firm-specific residual for each fiscal year t. The empirical measure of reporting quality is the absolute value of these residuals: RES $=\left|\mathrm{e}_{\mathrm{i}, \mathrm{t}+1}\right| \cdot{ }^{10}$ These residuals reflect the magnitude of future operating cash flows unrelated to current disaggregated earnings. In the empirical analysis that follows, I interpret lower absolute value as representing a higher quality of financial reporting, which corresponds to a higher level of cash flow predictability.

\subsection{Determinants of Financial Reporting Quality Choice}

The choice firms make about the quality of the financial information they report in their public financial statements reflects an analysis that weighs the expected benefits against the associated costs of disclosing high-quality information. Providing high-quality financial information is likely to reduce the information asymmetry between the firms and its investors, and to decrease agency costs. Given these benefits, one would expect firms to choose to provide the highest quality of financial information possible, absent any costs of disclosing such information. Thus, one would expect to observe a corner solution where the maximum reporting quality is chosen. In reality, this does not occur implying that there are costs associated with disclosure, such as direct costs (nonproprietary), litigation costs, and proprietary costs. Given such costs, firms would select an interior solution to financial reporting quality. Therefore, when investigating the

\footnotetext{
${ }^{9}$ This specification is used because it has the highest predictive ability compared to models that include multiple lags of cash flows from operations and accruals components (see Barth et al. [2001]).

${ }^{10}$ An alternative firm-year specific measure of reporting quality is the squared residual for that year. The correlation between this measure and the absolute value of residuals used in the study is 0.881 (p-value $<0.0001$ ) which suggest that these measures are highly correlated. The tenor of the results is very similar under this alternative specification.
} 
factors that determine a firm's reporting strategy decision, the associated costs must be considered.

To implement this approach, I estimate a Probit model that captures the effects of these factors and accounts for other variables that give rise to variation in financial reporting quality. Below I present the empirical model and outline the measures I use for firm-specific information demands, agency costs, and proprietary costs. A discussion of the control variables used in this Probit estimation follows my discussion of the model and measures.

In the first stage of the analysis, I estimate the following Probit model based on the variables discussed below:

$$
\begin{aligned}
& \text { QUALITY }_{\mathrm{i}, \mathrm{t}+1}=\phi_{0}+\phi_{1} \text { OWNER }_{\mathrm{i}, \mathrm{t}}+\phi_{2} \text { GROWTH }_{\mathrm{i}, \mathrm{t}}+\phi_{3} \text { CAPITAL }_{\mathrm{i}, \mathrm{t}}+\phi_{4} \text { HERF }_{\mathrm{i}, \mathrm{t}} \\
& \phi_{5} \text { LEVERAGE }_{\mathrm{i}, \mathrm{t}}+\phi_{6} \text { MARGIN }_{\mathrm{i}, \mathrm{t}}+\phi_{7} \mathrm{OC}_{\mathrm{i}, \mathrm{t}}+\phi_{8} \mathrm{~N}_{-} \text {SEG }_{\mathrm{i}, \mathrm{t}}+\phi_{9} \operatorname{SIZE~}_{\mathrm{i}, \mathrm{t}}+\xi_{\mathrm{i}, \mathrm{t}+1}
\end{aligned}
$$

Where:

$$
\begin{aligned}
\text { QUALITY }_{\mathrm{i}, \mathrm{t}+1} 1 & \text { if } \text { QUALITY }^{*}>0 \\
\text { and QUALITY }=0 \text { otherwise; }^{11} & \left(\left|\mathrm{e}_{\mathrm{i}, \mathrm{t}+1}\right|<\operatorname{Industry} \text { Median }\left|\mathrm{e}_{\mathrm{i}, \mathrm{t}+1}\right|\right)
\end{aligned}
$$

OWNER $_{i, t} \quad$ Natural log of the number of shareholders of firm i in year $t$ (in thousands; Compustat annual data item \#100) minus natural log of the median number of shareholders (in thousands) for the respective two-digit SIC code;

GROWTH $_{\mathrm{i}, \mathrm{t}}$ Current year's growth in sales, calculated as net sales for year t (Compustat annual data item \#12) less net sales of year $\mathrm{t}-1$, scaled by net sales for year $\mathrm{t}-1$;

CAPITAL $_{\mathrm{i}, \mathrm{t}}$ Net plant, property and equipment (Compustat annual data item \#8) divided by total assets (Compustat annual data item \#6);

HERF $_{\mathrm{i}, \mathrm{t}}$ The Herfindahl-Hirschman Index is calculated as the sum of squares of market shares in the industry. $\mathrm{HERF}=\sum_{\mathrm{i}=1}^{\mathrm{n}}\left[\mathrm{s}_{\mathrm{i}} / \mathrm{S}\right]^{2}$, where $\mathrm{s}_{\mathrm{i}}$ is the firm's sales and $\mathrm{S}$ is the sum of sales for all firms in the industry (defined by the two-digit SIC code), and $n$ is the number of firms in the industry;

LEVERAGE $_{\mathrm{i}, \mathrm{t}}$ Long term debt (Compustat annual data item \#9) plus debt in current liabilities (Compustat annual data item \#34) divided by total assets (Compustat annual data item \#6);

MARGIN $_{\mathrm{i}, \mathrm{t}}$ Gross margin percentage, calculated as the year t net sales (Compustat annual data item \#12) less cost of goods sold for the year (Compustat annual data item \#41), scaled by net sales;

\footnotetext{
${ }^{11}$ Instead of observing QUALITY*, which is the firm's net benefit of high quality financial reporting, I observe only a binary variable indicating the firm's reporting choice compared to its' industry peers.
} 
$\mathrm{OC}_{\mathrm{i}, \mathrm{t}} \quad$ Operating cycle for firm $\mathrm{i}$ at time $\mathrm{t}$, measured in days as $\frac{\left(\mathrm{AR}_{\mathrm{t}}+\mathrm{AR}_{\mathrm{t}-1}\right) / 2}{(\text { Sales } / 360)}+\frac{\left(\mathrm{INV}_{\mathrm{t}}+\mathrm{INV}_{\mathrm{t}-1}\right) / 2}{(\mathrm{COGS} / 360)}$, where $\mathrm{AR}$ is the firm's accounts receivable, INV is the firm's inventory, and COGS is the firm's cost of goods sold;

N_SEG ${ }_{i, t} \quad$ Number of two-digit SIC code industries that the firm is engaged in year $\mathrm{t}$; $\mathrm{SIZE}_{\mathrm{i}, \mathrm{t}} \quad$ Natural logarithm of market capitalization at the end of the fiscal year (year t), calculated as the closing price at fiscal year-end times the number of shares outstanding at fiscal year-end (Compustat annual data item \#199 times Compustat annual data item \#25);

$\xi_{\mathrm{i}, \mathrm{t}+1} \quad$ Error term assumed to have zero mean and constant variance.

The dependent variable in the model equation (2) specifies is a firm-year specific measure based on estimating equation (1) for each year t for each industry as defined in the previous section. I estimate the choice model in equation (2) across both firms and time, resulting in a pooled cross-sectional and time-series specification.

Firms have incentives to respond to investors' demands for firm-specific information since reducing information asymmetries between the firm and its investors can lower their cost of capital (see the survey articles by Healy and Palepu [2001] and Verrecchia [2001]). External demands for firm-specific financial information are expected to vary with the level of ownership concentration. Higher potential information asymmetry, especially among investors, and demands for firm-specific information is expected for firms with a highly dispersed investor base. Therefore, outsiders' demands for financial information from these firms is expected to be higher than for firms with high levels of ownership holdings. To capture the effect of ownership dispersion on the quality of financial reporting, I use the variable OWNER, which is the log of the number of shareholders of the firm adjusted by the log of the median number of shareholders in the firm's two-digit SIC code.

To proxy for the proprietary costs associated with the reporting decision, I use measures of firm's capital intensity, growth opportunities, and characteristics of its product market. If a product market's barriers to entry are relatively high, the associated proprietary costs of disclosure should be relatively low. High capital intensity is generally interpreted as a major barrier of entry (Piotroski [2003]). Therefore, capital intensity is thought to be positively associated with the quality of financial information. ${ }^{12}$ High entry

\footnotetext{
${ }^{12}$ In examining the effects of proprietary costs in the context of segment disclosures, Piotroski [2003] uses capital intensity as a barrier to entry and shows that it is positively associated with the fineness of segment reporting.
} 
costs to a market, as reflected by high capital requirements, create situations in which a large fraction of the capital costs are already sunk for incumbent firms, but are decision relevant to potential entrants. To capture the feature of capital intensity as a barrier to entry, I use the variable CAPITAL, which comprises net property, plant and equipment scaled by total assets. ${ }^{13}$

Another measure of proprietary costs relates to the firm's growth opportunities. The more innovative a market is and the more and heavily it relies on intangible knowledge, the more a firm should invest to retain its unique status and preserve future opportunities. Given that these future opportunities are positively associated with proprietary costs, I use GROWTH, which I define as the current year's percentage change in sales, as a proxy for future opportunities that the firm needs to protect. I expect that it will be negatively associated with the level of future cash flow predictability.

The literature identifies existing competition in a firm's product market as being associated with proprietary costs. Competition thus influences a firm's disclosure decisions. However, theoretical predictions about the relation between product market competition and disclosure are mixed. Some models predict that more competition within the product markets increases disclosure. Darrough and Stoughton [1990], identifying an endogenous disclosure cost, show that current competitors might prevent future entry by providing more informative disclosures in more competitive industries. On the other hand, Verrecchia [1983], identifying an exogenous cost of disclosure, suggests that current competition in the product market discourages disclosures, and predicts that firms provide less informative disclosures in more competitive product markets .

In order to account for product market competition, I measure the concentration rate of each industry using the Herfindahl-Hirschman Index. I calculate the HerfindahlHirschman Index as HERF $=\sum_{i=1}^{n}\left[s_{i} / S\right]^{2}$, where $s_{i}$ is the firm's sales, $S$ is the sum of sales for all firms in the industry (defined by the two-digit SIC code), $\frac{S_{i}}{S}$ is the market share of firm $\mathrm{i}$, and $\mathrm{n}$ is the number of firms in the industry. ${ }^{14}$ This index accounts for the relative size and distribution of firms in a market. The index approaches zero when a market

\footnotetext{
${ }^{13}$ As a sensitivity analysis, I repeated the analysis by using capital expenditures, a flow variable. The reported results are not affected by this change.

${ }^{14}$ One can argue that the Herfindhal-Hirshman Index is a good proxy of pre-entry competition in a particular industry. For example, in concentrated industries where barriers to entry are low, one can expect competition to increase within a short period of time.
} 
consists of a large number of firms of relatively equal size (a situation that approximates perfect competition). The index increases both as the number of firms in the market decreases and as the disparity in size between those firms increases. The higher the index, the higher the potential for the exercise of market power.

Given the different analytical models' suggestions, I do not have a specific prediction about the association between the quality of financial information and the level of competition, as captured by the concentration ratio. On the one hand, higher concentration ratios proxy for monopoly rents, but on the other hand, this may be one reason why the industry is highly concentrated. Thus the concentration ratio is likely to be a proxy for high entry costs (high barriers to entry). However, if the concentration ratio is a good proxy for post-entry competition (consistent with Verrecchia [1983]), then one would expect a positive relation between financial reporting quality and the level of industry concentration. Such an expectation implies a negative relation between the level of competition within an industry and financial reporting quality.

To address the difference between the arguments raised in Verrecchia [1983] and Darrough and Stoughton [1990], I include the variable MARGIN, defined as sales revenue net of cost of goods sold, scaled by net sales. More profitable firms with higher gross margins attract future competition and face higher threats of potential entrants. Thus the higher is the firm's profitability, captured by its gross margin, the more is the proprietary cost of providing higher quality of financial information expected to be. Given the evidence in analytical models (e.g., Dye [1985a, 1986]) and empirical studies (e.g., Lang and Lundholm [1993]), which suggest that firm performance is positively associated with disclosure, I must append a caveat to this prediction. This argument biases against finding a negative relation between firm's profitability and financial reporting quality.

The presence of agency costs gives rise to a demand for monitoring, and the information a firm's financial statements provide may be used to mitigate agency costs (Jensen and Meckling [1976]). Highly leveraged firms have higher agency costs and thus a greater demand for monitoring. ${ }^{15}$ Therefore, I predict reporting quality to vary with a firm's capital structure (Leftwich et al. [1981]). If the financial information provided in the firm's annual report is complementary to the monitoring information debt providers

${ }^{15}$ Capital structure is an endogenous variable for the firm as well. To address this concern, the specification of equation (2) uses lagged values of the explanatory variables in contrast to a contemporaneous specification. 
use, I expect more leveraged firms to provide financial information of higher quality. If debt providers use substitute information channels to acquire monitoring information, this will decrease the likelihood that the previously prediction relation holds true. I use the variable LEVERAGE, which is the firm's total debt to total asset ratio, to capture this determinant on financial reporting quality.

\section{Control Variables:}

Differences across firms could influence the future performance and predictability of their future cash flows. Dechow, Kothari and Watts [1998] show that ability of earnings to predict future cash flows depends on the firm's operating cash cycle. Dechow and Dichev [2002] claim that longer operating cycles induce more uncertainty, making accruals noisier and less helpful in predicting future cash flows. To control for the uncertainty associated with the operating environment of the firm, I include in equation (2) a proxy for the length of the operating cycle (OC), where OC = $\frac{\left(\mathrm{AR}_{\mathrm{t}}+\mathrm{AR}_{\mathrm{t}-1}\right) / 2}{(\mathrm{Sales} / 360)}+\frac{\left(\mathrm{INV}_{\mathrm{t}}+\mathrm{INV}_{\mathrm{t}-1}\right) / 2}{(\mathrm{COGS} / 360)}$ (measured in days). The operating cycle variable captures variation in future cash flow predictability that is likely not predetermined. To further address how the complexity of the firm's operating environment affects variation in information quality, I also include the number of line of businesses that a firm engages in (N_SEG). To further control for the firm's informational environment, I include as a control variable the firm's SIZE, defined as the natural logarithm of market capitalization at the end of the fiscal year.

\subsection{Economic Consequences of Financial Reporting Quality}

I use four proxies for capital market consequences of financial reporting quality as the dependent variables in the second stage estimation: 1) the firm's cost of equity capital estimated using a model developed by Ohlson and Juettner-Nauroth [2000], 2) the firm's bid-ask spread (a proxy for the level of information asymmetry), 3) the dispersion in analysts' earnings forecasts (a proxy for uncertainty and estimation risk), and 4) the number of analysts following the firm (a proxy for the informativeness of the firm's information environment). The main hypothesis that I test is whether providing financial information of higher quality is associated with capital market valuation benefits.

To test the economic consequences associated with reporting quality, I estimate the following pooled cross-sectional time-series model:

$$
\text { CONSEQUENCES }_{\mathrm{i}, \mathrm{t}}=\alpha_{0}+\beta_{1}{ }^{\prime} \mathrm{X}_{\mathrm{it}}+\beta_{2}{ }^{\prime} \mathrm{QUALITY}_{\mathrm{i}, \mathrm{t}}+\varepsilon_{\mathrm{i}, \mathrm{t}}
$$


In equation (3) the dependent variable is one of the four proxies for capital market consequences, $X_{i t}$ represents a vector of control variables, and QUALITY ${ }_{i, t}$ is an empirical measure of reporting quality. As discussed previously, QUALITY is likely to be correlated with the error term $\varepsilon$, which creates an endogeneity problem. This endogeneity is generally due to omitted correlated variables. As shown in the previous section, financial reporting quality may be determined by factors that are not captured by the control vector $\mathrm{X}$.

This endogeneity problem can be solved through an instrumental variables approach. Following this approach, the researcher must identify a vector of observable variables that do not appear in equation (3) and are not correlated with the error term $\varepsilon$, but are correlated in part with the variable QUALITY. The variables identified in section 3.2 meet this requirement.

I estimate a two-stage procedure (see Barnow, Cain, and Goldberger [1980] and Wooldridge [2002]), in the first stage of which I estimate a Probit financial reporting quality choice model. Using the fitted probabilities from this Probit model as an instrumental variable for the quality measure (FITQUALITY 1 ), I estimate in the second stage an OLS regression of capital market/valuation benefits proxies on firm characteristics and this instrumental variable. ${ }^{16}$ Following Maddala [1983, p. 118-121], I do not include in the Probit model (equation (2)), a variable that proxies for any of the capital market benefits that I use in the second OLS regression. Including the dependent variable of the second stage equation in the Probit model will lead to a logically inconsistent specification, unless the capital market benefit coefficient is restricted to be equal to zero. It is important to note that the first stage Probit model need not be perfectly specified. ${ }^{17}$ All that is required is that the variables identified as determinants of the reporting quality choice and not appearing in the vector $\mathrm{X}$ in equation (3) be correlated with QUALITY. As the correlation matrix reported in Table 3 indicates, this is indeed the case.

The use of a binary variable to measure reporting quality can introduce measurement error into the analysis, since such a variable may disregard valuable information. I address this concern by using a second instrumental variable

\footnotetext{
${ }^{16}$ In order to derive correct inferences, the standard errors are adjusted to address the correlation between the error term of the probit selection model and the error term in the second stage equation (see Maddala [1983, p. 252-256]).

${ }^{17}$ See Wooldridge [2002, p. 623-624] for a detailed discussion and Appendix A.
} 
(FITQUALITY 2 ), obtained from an OLS regression of ADJ_RES (defined as the difference between RES and the industry-median RES) on the set of variables identified in section 3.2. The tables report the results of using ADJ_RES, the indicator variable QUALITY, the instrumental variable FITQUALITY 1 and the second instrumental variable FITQUALITY 2 as alternative measures of reporting quality.

The following specific models are estimated in the second stage across firms and time:

$$
\begin{aligned}
& R_{e, t,}=\rho_{0}+\rho_{1} \text { BETA }_{i, t}+\rho_{2} \operatorname{SIZE}_{i, t}+\rho_{3} B_{-} M_{i, t}+\rho_{4} \text { LEVERAGE }_{i, t}+\rho_{5} E_{-} \text {GROWTH }_{i, t}+\rho_{6} F Q_{i, t}+\vartheta_{i, t} \\
& \operatorname{SPREAD}_{e i, t}=\chi_{0}+\chi_{1} \operatorname{SIZE}_{i, t}+\chi_{2} \operatorname{VOLUME}_{i, t}+\chi_{3} \operatorname{STDRET}_{i, t}+\chi_{4} \operatorname{LIST}_{i, t}+\chi_{5} F_{i, t}+\zeta_{i, t} \\
& \operatorname{DISP}_{e_{i, t}}=\lambda_{0}+\lambda_{1} \text { SIZE }_{i, t}+\lambda_{2} \text { SURP }_{i, t}+\lambda_{3} \text { ANALYST }_{i, t}+\lambda_{4} F Q_{i, t}+\pi_{i, t} \\
& \operatorname{ANALYST}_{e, t,}=\varpi_{0}+\varpi_{1} \operatorname{SIZE}_{i, t}+\varpi_{2} \mathrm{EPS}_{i, t}+\varpi_{3} R O A_{i, t}+\varpi_{5} \mathrm{GROWTH}_{i, t}+\varpi_{6} \mathrm{FQ}_{i, t}+\psi_{i, t}
\end{aligned}
$$

Where:

$\mathrm{R}_{\mathrm{e}, \mathrm{t}} \quad$ Implied Cost of equity capital for firm $\mathrm{i}$, year $\mathrm{t}$, using the Ohlson and Juettner-Nauroth [2000] model;

BETA $_{i, t} \quad$ The market beta for firm $i$ in year $t$, estimated using a rolling window of five years of monthly returns where the CRSP weighted market return is used as the market return;

SIZE $_{\mathrm{i}, \mathrm{t}} \quad$ Natural logarithm of market capitalization for firm $\mathrm{i}$, at the end of the fiscal year t, calculated as the closing price at fiscal year-end times the number of shares outstanding at fiscal year-end (Compustat annual data item \#199 times Compustat annual data item \#25);

B_M $M_{i, t} \quad$ Book-to-Market ratio, where market value of equity is calculated as the closing price at fiscal year-end times the number of shares outstanding at fiscal year-end (Compustat annual data item \#199 times Compustat annual data item \#25), divided by the book value of common equity (Compustat annual data item \#60);

LEVERAGE $_{\mathrm{i}, \mathrm{t}}$ Long term debt (Compustat annual data item \#9) plus debt in current liabilities (Compustat annual data item \#34) divided by total assets (Compustat annual data item \#6) for firm i at year t;

E_GROWTH ${ }_{i, t}$ Expected long term growth in earnings, defined as the percentage change in the mean two-year ahead earnings forecast (obtained from Zacks) from the current earnings realization (Compustat annual data item \#58); 
$F Q_{i, t} \quad$ Financial reporting quality measure, which is equal to one of the following: QUALITY: Indicator variable equal to one if $\mathrm{RES}_{\mathrm{i}, \mathrm{t}} \leq$ Industry median RES; ADJ_RES: Industry-adjusted RES $_{\mathrm{i}, \mathrm{t}}$; FITQUALITY : Instrumental variable which is equal to the fitted probabilities obtained from a Probit regression, where the dependent variable is QUALITY; FITQUALITY $_{2}$ : Instrumental variable which is equal to the fitted value obtained from an OLS regression, where the dependent variable is ADJ_RES;

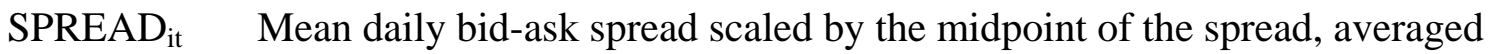
over the 12 months starting as of June subsequent to fiscal year

$$
\text { t, } \frac{\text { ASK }- \text { BID }}{(\text { ASK }+ \text { BID }) / 2} \text {; }
$$

VOLUME $_{\text {it }} \quad$ Natural logarithm of the daily number of shares traded for firm i averaged over the 12 months starting as of June subsequent to fiscal year t; STDRET $_{\text {it }} \quad$ Firm i's standard deviation of daily holding period return averaged over the 12 months starting as of the June subsequent to fiscal year t;

LIST $_{\text {it }} \quad$ A dummy variable which equals 1 if firm i was listed on NASDAQ over the corresponding period and zero for NYSE/AMEX firms;

DISP $_{\mathrm{i}, \mathrm{t}} \quad$ Standard deviation of analysts’ forecasts of year $\mathrm{t}$ earnings per share (Zacks) for firm i, measured in June following fiscal year t-1, scaled by beginning of period price;

SURP $_{i, t} \quad$ Absolute value of the difference between current year's earnings per share (Compustat annual data item \#58) and the previous year earnings per share, scaled by average total assets of the firm;

ANALYST $_{i, t}$ Number of analysts issuing forecasts at the same time DISP was calculated (Zacks);

EPS $_{\mathrm{i}, \mathrm{t}} \quad$ Earnings per share before discontinued operations and extraordinary items (Compustat annual data item \#58) adjusted for stock splits and dividends, for firm i at year $\mathrm{t}$;

$\mathrm{ROA}_{\mathrm{i}, \mathrm{t}} \quad$ Return on assets for firm $\mathrm{i}$ at year $\mathrm{t}$, calculated as earnings before discontinued operations and extraordinary items (Compustat annual data item \#18) divided by total assets (Compustat annual data item \#6);

GROWTH $_{i, t}$ Growth in net sales for firm i, calculated as net sales for year $t$

(Compustat annual data item \#12) less net sales of year $t-1$, scaled by net sales for year $\mathrm{t}-1 ;{ }^{18}$

$\zeta_{i, t}, v_{i, t}, \pi_{i, t}, \psi_{i, t}$ Error terms assumed to have zero mean and constant variance.

Given that my analysis is focused on long term capital market consequences, I perform the tests over annual windows. Specifically, following Gebhardt et al. [2001] and Guay et al. [2003], I estimate the firm-specific implied cost of capital using the stock price as of July 1 each year. Following the approach used in these studies, I collect

\footnotetext{
${ }^{18}$ As an alternative measure of growth opportunities, I used the firm's dividend payout ratio since this variable may provide a signal regarding the firm's future growth opportunities. The significance of the reported results is unchanged using this alternative measure.
} 
analysts' earnings forecasts from June of each year, rather than from different points in the calendar year. Use of the stock price as of July 1, assumes that capital market participants are aware of the firm's financial reporting quality choice for the most recent fiscal year ending prior to June. This methodology makes sure that the implied cost of capital is an ex ante proxy for risk-premium, which relies on financial information known prior to its estimation date. I apply this same procedure to the other measures of capital market consequences, bid-ask spreads and analysts' forecasts properties. ${ }^{19}$

Equations (3a)-(3d) are estimated using both pooled cross-sectional time-series regressions and Fama-MacBeth regressions. I report the results of the Fama-MacBeth regressions, for which I run cross-sectional regressions annually and then average the annual coefficients across the sample years from 1987-2001. I use the standard deviation of the coefficients across the fifteen sample years to compute the t-statistics: $t=\frac{\bar{\beta}}{\sigma_{\beta} / \sqrt{n}}$;

where $\bar{\beta}$ is the average coefficient based on the yearly regressions, $\sigma_{\beta}$ is the time-series standard deviation corresponding to each coefficient, and $\mathrm{n}$ is the number of years. Since the autocorrelation between the coefficients in the annual regressions can affect the true standard errors and thus inflate the t-statistics, I correct the t-statistics in a manner consistent with Bernard [1995].

\subsubsection{The Firm's Cost of Equity Capital}

Following Barone [2002] and Francis et al. [2003a, 2003b], lower quality financial reporting leads to a greater uncertainty and ultimately to higher information risk. If this risk cannot be diversified, it will result in a higher cost of equity capital. In such a case, one will expect to find that $\rho_{6}>0$ (equation (3a)) when the independent variable is either ADJ_RES or FITQUALITY 2 , and $\rho_{6}<0$ when the independent variable is either the indicator variable QUALITY or the instrumental variable FITQUALITY 1 (the higher FITQUALITY 1 , the higher the probability of reporting high-quality financial information, which suggests a lower cost of equity capital).

Following this rationale, I test the association between the empirical measures of reporting quality outlined in section 3.2 and an implied cost of equity capital metric

\footnotetext{
${ }^{19}$ For equations (3b)-(3d), I have also estimated the relevant variables averaged over the 12 months starting as of the last day of the first quarter subsequent to fiscal year t. The results were similar to those reported.
} 
estimated using the model presented in Ohlson and Juettner-Nauroth [2000] (hereafter referred as the OJ model). Previous studies have used different measures for the cost of capital. Since the cost of capital is not an observed phenomenon, one needs to estimate it precisely. Some of the cost of capital estimation methods used in the literature are based on the Fama-French three-factor model (Fama and French [1993]). As Fama and French [1997] point out, cost of capital estimates based on the three-factor model are imprecise, both at the firm level and the industry level. Another alternative is to proxy for the cost of capital by using realized stock returns. This approach has problems too, given that the correlations between expected returns and ex post realized returns are weak (Elton [1999]). These approaches have led researchers to infer ex ante the cost of capital using an implied cost of capital approach. Following this approach, assuming a valuation model, one estimates the implicit cost of capital using the current stock price and observable proxies for market expectations of future cash flows or earnings (usually analysts’ earnings forecasts).

The OJ model generalizes the Gordon growth model by allowing the short term growth rate to differ from the perpetual growth rate. The OJ model has two appealing features. First, it uses earnings rather than dividends, it does not require any forecasts of book value of equity or return on equity, and it does not make any assumptions regarding long-term industry profitability. This implies that one need not make any assumptions either about the firm's payout policy, beyond the expected dividends of next period, or about clean surplus. Second, the OJ model is parsimonious; it assumes that the short-term growth rate decays asymptotically to the perpetual growth rate, which equals the longterm economic growth rate.

The results documented in Gode and Mohanram [2002] suggest that the OJ riskpremium metric is a robust and appealing measure of the cost of capital. ${ }^{20}$ Specifically, they provide evidence that the OJ metric correlates with known risk factors (such as book-to-market, size, growth, and beta) in predicted ways when one uses a pooled crosssectional time-series setting, and also when one runs annual regressions. Moreover, Gode and Mohanram [2002] report that the OJ cost of capital metric has an economically significant association with ex post stock returns. ${ }^{21}$ Overall, their results suggest that in

\footnotetext{
${ }^{20}$ The main assumptions and results of the model are described in detail in Appendix B.

${ }^{21}$ One way to evaluate an ex ante measure of risk-premium is to test its correlation with ex post realized stock returns. Although Gode and Mohanram [2002] provide evidence that risk-premium metrics based on residual income valuation
} 
spite of the model's parsimoniousness and its ignoring of book values and industry profitability, the OJ metric provides risk-premium estimates that reflect the market's perception of risk.

Previous studies have identified a number of risk factors that are associated with expected returns. The Capital Asset Pricing Model (CAPM) implies that the firm's expected return is positively associated with its market beta. I include BETA in equation (3a) to control for this risk factor. A positive relation is expected between BETA and the cost of capital.

Given the evidence documented in the finance literature, in order to proxy for the firm's total information environment, I include a measure of the firm's size in equation (3a). I use the firm's market capitalization and expect a negative association between SIZE and the implied cost of capital. ${ }^{22}$

Fama and French [1992] find that, compared to lower book-to-market firms, higher book-to-market firms earn higher realized returns. To control for risk factors associated with this measure, I include in equation (3a) B_M, the firm's book-to-market ratio, and expect a positive association between this variable and the cost of capital.

The majority of the valuation models used both in the accounting and finance literature imply that, ceteris paribus, as future growth in the payoff stream increases, the expected return also increases (La Porta [1996]). Given my focus on expected returns rather than on realized rates of return, I expect to find a positive association between the expected growth in the firm's profitability and the cost of capital. To capture this prediction, I include E_GROWTH, which is calculated as the percentage change in the mean two-year ahead earnings forecast from the current earnings realization.

\subsubsection{Financial Reporting Quality and Information Asymmetry}

Analytical research has shown that, in addition to the release of public financial information, the quality of financial disclosures should also affect information asymmetries in the capital markets (Diamond and Verrecchia [1991]). Copeland and Galai [1983] and Glosten and Milgrom [1985] suggest that bid-ask spreads are associated with investors' perceived levels of information asymmetry. To examine whether the

models result in higher correlations, the sign and significance of the results are sensitive to the assumptions one makes on the level of industry profitability (in particular the rate of convergence to the median-industry ROE and its effect on the terminal value calculation), and the inclusion or exclusion of loss firms.

${ }^{22}$ All the tests were repeated using the firm's total assets instead of its market capitalization in order to avoid any mechanical relation between market value and the implied cost of capital. The results were similar to those reported in the tables. 
quality of public financial statements affects perceived levels of information asymmetries, I focus on the firms' bid-ask spreads (equation (3b)). Given the theoretical predictions outlined in Section 2, I expect that, as the quality of accounting information provided in the firm's financial reports increases, the level of information asymmetry decreases. According to this prediction, $\chi_{5}<0$ (corresponding to the instrumental variable FITQUALITY $_{1}$ ) in equation (3b), which suggests that higher quality financial information is associated with lower relative bid-ask spreads.

Prior studies in the accounting literature use bid-ask spreads to test the effects of earnings announcements and firms' disclosures policies on the level of information asymmetry (Lee, Mucklow, and Ready [1993], Healy, Hutton, and Palepu [1999], Leuz and Verrecchia [2000]). Given the evidence presented in these studies, I use the mean daily bid-ask spread, scaled by the mid-point of the spread as the dependent variable in equation (3b).

In addition to the financial reporting quality variable, the regression equation includes other determinants that previous studies have found to be associated with bidask spreads. In particular, I control for the trading volume in the firm's stock, the firm's size, variance of stock returns, and the exchange the firm is listed on. The dummy variable LIST is assigned a value of one if the firm is listed on NASDAQ and zero for NYSE/AMEX firms. LIST is included to control for the institutional differences between the different exchanges. This control variable reflects the finance literature's growing awareness of the importance of institutional differences across stock exchanges in determining the behavior of securities. Given concerns regarding the use of bid-ask spreads as a proxy for information-asymmetry for long horizon specifications, I also examine the properties of analyst forecasts. ${ }^{23}$

\subsubsection{Effects of Financial Reporting Quality on Analyst Forecasts and Following}

Financial statements that provide higher quality information are predicted to reduce investor uncertainty and lower the information risk for a specific firm. In equation (3c) and (3d), I test the effect of reporting quality on analysts' behavior, as captured by the standard deviation of analysts' annual earnings estimates for a given year and the number of analysts providing a forecast in a given period.

\footnotetext{
${ }^{23}$ The use of bid-ask spreads as a proxy for information asymmetry suffers from a few deficiencies. Given the different components of the bid-ask spread, such as order processing costs and inventory costs, the total bid-ask spread might be a rough proxy for the adverse selection component.
} 
The focus on analyst forecast dispersion is motivated by Barry and Brown [1985], who argue that this variable is an appropriate proxy for estimation risk. Firms have incentives to reduce the dispersion among analysts, and hence the overall dispersion in capital market earnings expectations, in order to indirectly reduce the firm's cost of equity capital. Given the existing literature's findings, I include variables identified as being associated with the variation in analysts' forecasts dispersion: SIZE, SURP, and ANALYST. Firm size and the number of analysts following a firm have been found to be positively related to analyst forecast accuracy (negatively associated to forecast dispersion). SURP is included in equation (3b) to capture the difficulty in forecasting earnings.

Previous research has suggested that greater analyst following improves the liquidity of the firm's stock (e.g., Diamond and Verrecchia [1991]). To examine whether analyst following is positively associated with financial reporting quality, I estimate equation (3d). I include the following control variables, which previous studies have shown to be associated with analyst following: SURP, SIZE, ROA, and GROWTH.

\section{Data and Empirical Results}

\subsection{Sample Selection}

I base my analysis on data obtained from the following sources: the 2002 COMPUSTAT annual industrial and research files, the 2002 CRSP files, and Zacks Investment Research (Zacks) data for 1987-2001. Previous studies (e.g. Collins and Hribar [2002], Dechow, Kothari, and Watts [1998]) document and discuss how using balance sheet accounts to derive cash flow from operations can lead to problems like noisy and biased estimates. The cash flow from operations reported in the statement of cash flows subsequent to the Statement of Financial Accounting Standard No. 95 (SFAS No.95) is likely to have less measurement error. I therefore use the 1987-2001 period since cash flow from operations (Compustat annual data item \#308) calculated from the statement of cash flows only becomes available in 1987, following SFAS No. $95 .{ }^{24}$

I exclude firms in SIC codes 6000-6999 (financial institutions, insurance, and real estate companies) since the cash flow predictability empirical model developed does not reflect their activities. Next, I restrict the analysis to firms that do not have any missing

\footnotetext{
${ }^{24}$ SFAS No. 95 requires firms to present a statement of cash flows for fiscal years ending after July 15, 1988. Some firms early-adopted SFAS No. 95, so my sample begins in 1987. This sample selection is consistent with Barth et al. [2001].
} 
data for the variables used in the empirical analysis, and I exclude observations with the most extreme one percent value of their distributions. ${ }^{25}$ I require that each firm has at least one year of past and future cash flow from operations. These criteria yield a primary sample of 16,664 firm-year observations, representing 2,363 firms.

\subsection{Descriptive Statistics}

An examination of the descriptive statistics reported in Table 2 suggests that the sample firms are large relative to the COMPUSTAT population, with mean (median) total assets of \$1,799 million (\$288 million) and mean (median) market value of equity of $\$ 1,848$ million ( $\$ 262$ million), profitable (return on assets of about 0.034), and growing (median sales growth of 0.089 ).

The operating cycle (OC) has a mean of 136 days and a standard deviation of 122 days. This indicates that the majority of the firms in the sample have an operating cycle of less than one year. This finding is consistent with the fact that most accruals reverse within one year (Dechow and Dichev [2002]). The mean (median) of HERF (the concentration ratio) is $0.27(0.25)$, indicating that the sample represents rather competitive industries.

Table 3 provides Pearson (above the diagonal) and Spearman (below the diagonal) correlations among the variables used to estimate equation (2). As predicted, the quality of financial reporting, as measured by the indicator variable QUALITY, is significantly and positively associated with OWNER, LEVERAGE, and CAPITAL (QUALITY takes the value of one if RES, the residuals obtained from a regression of future operating cash flows on current operating cash flows and accrual components, is lower than the two-digit SIC industry median and zero otherwise). On the other hand, QUALITY is significantly negatively correlated with HERF and GROWTH. The positive association between OWNER and QUALITY suggests that firms with a less concentrated investor base, who are likely to face higher demands for firm-specific information, provide a higher quality of information. Consistent with the prediction regarding LEVERAGE, a positive correlation implies that more leveraged firms tend to provide financial information of higher quality.

The level of industry concentration, as captured by the concentration ratio HERF, is negatively correlated with the reporting quality measure. This negative correlation

\footnotetext{
${ }^{25}$ The results and inferences reported are not affected by eliminating the extreme values of the distribution.
} 
suggests that the higher the concentration ratio, the less competitive the industry, and the more likely competitors are to engage in anti-competitive activity, the less likely it is that future cash flows can be accurately predicted from the public financial information provided in annual reports. Taken together, the univariate analysis shows that the quality of financial reporting, as empirically measured by QUALITY, is positively associated with a proxy for firm-specific information demand and negatively associated with different proxies for proprietary costs. The latter finding implies that the higher the proprietary costs proxies, the lower the quality of the financial information that firms disclose in their financial reports.

The statistically significant correlations reported in Table 3 between the reporting quality measure and some of its identified determinants highlight the importance of using a two-stage estimation method to test the association between reporting quality and its associated economic consequences. Failure to do so will result in an econometric problem, which would influence and affect both the results and the interpretations made from the analysis (for a detailed discussion, please see the econometric discussion presented in Appendix A).

\subsection{Multivariate Analysis - Determinants of Financial Reporting Quality}

As discussed in section 3.1, I estimate a Probit model to examine the determinants of reporting quality. I present results of a multivariate analysis from estimating the Probit model of equation (2) in Table 4. Coefficients and p-values are reported in the middle column. The last column presents an estimate of the marginal probability effect suggested by the coefficient. The marginal probability represents the change in the probability of providing high quality financial information for a one standard deviation change in the respective independent variable. ${ }^{26}$ Firms with a more diverse ownership base (OWNER) and higher leverage (LEVERAGE) are significantly more likely to provide high-quality financial information. These two factors are the strongest determinants of whether firms choose a high or low reporting quality. These results suggest that investors' demands for financial information and monitoring devices influence the likelihood of firms providing high-quality information.

\footnotetext{
${ }^{26}$ The effect of a standard deviation change in the independent variable is calculated by multiplying the estimated coefficient by $\phi\left(\beta^{\prime} \mathrm{X}\right)$ where $\phi$ is the probability density function for the normal distribution, and $\beta^{\prime} \mathrm{X}$ is computed at the mean values of the independent variables.
} 
In addition, I find evidence that proprietary costs affect the reporting quality decision. In particular, the results indicate that competition within an industry, measured by HERF (the Hefindahl-Hirshman Index), affects reporting quality. The coefficient of HERF and its marginal probability are significantly negative, suggesting that firms in less competitive industries are less likely to report high-quality information. This result is consistent with the findings of Harris [1998], who demonstrates that firms are less likely to disclose operations in less competitive industries as business segments. In other words, a higher quality of information prevails in more competitive environments. This result is consistent with theoretical models predicting less disclosure in less competitive markets (e.g., Hayes and Lundholm [1996]). On the other hand, this result is not consistent with disclosure models that predict that firms respond to higher levels of competition by providing less information (e.g., Verrecchia [1983]).

CAPITAL has a significant positive effect on reporting quality, which suggests that more capital-intensive firms provide financial information that more precisely predicts future cash flows. One explanation for this finding is that capital intensity acts as a barrier to entry for future competitors in the product market. Therefore, such firms incur less proprietary costs in providing financial information, as reflected in the reported disaggregated earnings, which are more informative regarding future performance. The coefficient on GROWTH, is not significant at conventional levels, though its direction is as predicted.

The results indicate that the larger the firm, the higher the quality of its financial reporting. This finding is consistent with previous research documenting a positive relation between firm size and disclosure policy decisions (e.g., Lang and Lundholdm [1993]). The significant coefficient on MARGIN bears out the hypothesis that more profitable firms (as reflected in higher realize margins) have the higher proprietary costs associated with lower reporting quality. The negative coefficient on MARGIN is consistent with the findings in Piotroski [2003], who interprets MARGIN as a proxy for proprietary costs, but inconsistent with previous findings that firm performance is positively related to disclosure policies (e.g., Lang and Lundholm [1993]).

\subsection{Second-Stage Analysis: Economic Consequences of Financial Reporting Quality}

In this section I examine the capital markets consequences associated with financial reporting quality choices. I examine the effects of financial reporting quality on 
four proxies for capital market valuation consequences: 1) the firm's cost of capital, 2) the mean daily bid-ask spread (a proxy for the firm's perceived information asymmetry), 3) the dispersion in analysts' earnings forecasts (a proxy for uncertainty and estimation risk), and 4) the number of analysts following the firm (a proxy for the informativeness of a firm's information environment).

Using either the fitted probabilities from estimating a Probit model in the first stage as an instrumental variable for the reporting quality measure (FITQUALITY 1 ) or the fitted values from a OLS regression (FITQUALITY 2 ) where the dependent variable in the first stage estimation is ADJ_RES (the industry-adjusted RES), I estimate an OLS regression of capital market/valuation benefits proxies on firm characteristics and the financial reporting quality measure.

\subsubsection{Cost of Equity Capital}

Table 5 presents the results obtained using industry-adjusted earnings-price ratios (E/P) as a measure of risk-premium. These results serve as a benchmark, since a generic Gordon growth model takes the following form: $P=\frac{E}{R_{e}-g}$, and $R_{e}=\frac{E}{P}+g$.

The discussion in section 3.3.1 shows that the OJ model extends the Gordon growth model by allowing the short-term growth to differ from the perpetual growth rate. The $\mathrm{E} / \mathrm{P}$ ratio can therefore be used as a benchmark measure of the risk-premium. All four columns in Table 5 support the assertion that $\mathrm{E} / \mathrm{P}$ is negatively associated with long-term growth (E_GROWTH). This relation is expected, since the E/P ratio equals the risk premium $R_{e}$ minus the growth rate. The first two columns suggest that higher reporting quality is associated with lower $\mathrm{E} / \mathrm{P}$ ratios $\left(\delta_{5}^{\text {QUALITY }}=-0.0022\right.$, t-statistic $=3.59$; $\delta_{5}^{A D J_{-} R E S}=0.1015$, t-statistic $\left.=6.09\right)$. However, controlling for the reporting quality choice and using the instrumental variables FITQUALITY 1 and FITQUALITY 2 , I find that reporting quality is not significantly associated with the E/P ratio. This finding suggests that lower financial reporting quality does not necessarily imply a higher riskpremium.

Table 6 presents the results of examining whether reporting quality explains the variation in firm-specific implied cost of capital measures. Columns A and B of Table 6 report the results of estimating equation (3a), using QUALITY, the indicator variable and ADJ_RES (the industry-adjusted residuals obtained from estimating equation (1)) as the 
empirical measures of reporting quality. Both earnings quality metrics are significantly associated with the cost of capital after controlling for expected growth and other risk factors identified in the accounting and finance literature. ${ }^{27}$ These results imply that firms providing high-quality accounting information enjoy a lower cost of capital. Given these results, one could conclude that the reporting quality is an information risk factor which is priced by capital market participants, over and beyond additional risk factors priced by the market, such as beta, size, and book-to-market.

The results listed in Column $\mathrm{C}$ and $\mathrm{D}$ of Table 6, however, suggest that this conclusion does not hold up when one acknowledges the endogeneity that characterizes the reporting quality decision. If the specification estimated in Columns $\mathrm{A}$ and $\mathrm{B}$ is subject to a correlated omitted variables problem (as shown in Appendix A), the estimated value of the coefficient corresponding to the particular treatment effect may be biased and inconsistent. The instrumental variables FITQUALITY 1 and FITQUALITY 2 are not significant in explaining the cross-sectional variation in the cost of equity capital estimates over and above previously documented risk factors which influence the cost of equity capital. Consistent with findings in the literature, I find that the cost of equity capital proxy used in this study is associated with firm size and expected growth, as well as with risk factors measured by market beta, the book-to-market ratio, and financial leverage. These results demonstrate the importance of accounting for the endogenous feature of financial reporting decisions. ${ }^{28}$ Failing to do so significantly affects the conclusions researchers draw from empirical analyses. The discrepancy between the significant associations reported in Columns A and B and the results reported in Columns $\mathrm{C}$ and D may be due to omitted correlated factors affecting reporting quality. Once these factors are accounted for, any conclusions and inferences must reflect the results reported in Columns C and D.

Based on these results, one cannot infer that increasing the quality of reported earnings will necessarily result in a decreased cost of capital. These findings are consistent with some of the evidence documented in Francis et al. [2003b] regarding the pricing effects of discretionary accruals quality. When these authors distinguish between

\footnotetext{
${ }^{27}$ A higher value of ADJ_RES implies a lower quality of earnings, whereas QUALITY=1 represent a high quality reporting firm-year observation.

${ }^{28}$ In the presence of multicollinearity, OLS estimation will provide more robust estimates than 2SLS. To address this problem, I compute the variance inflation factors for each regression. The results suggest that multicollinearity is not a problem.
} 
two components of accruals quality, a non-discretionary and a discretionary one, they find that the discretionary component (measured as a raw variable) is not significantly associated with industry-adjusted earnings-price ratios. Using a different empirical methodology than the one I use in this study, Francis et al. [2003b] generally find that the “discretionary component of accruals quality, on average, has a significantly smaller pricing effect than the innate component of accruals quality" (page 39), and "we find that the cost of capital effect of a unit of discretionary accruals quality is both smaller and (often) less statistically significant than the cost of capital effect of a unit of innate accruals quality” (page 5).

In summary, the results in this section suggest that the reporting quality measure used in the analysis is not an additional priced risk factor over and beyond previously documented risk factors. In other words, lower financial reporting quality does not result in a significant higher cost of equity capital.

\subsubsection{Measurement Error in the Implied Cost of Capital Estimate}

Implied cost of capital estimates make use of analysts' earnings forecasts of both short-term and long-term earnings. Using analysts' forward looking information might provide better estimates of the cost of capital than estimates obtained from asset pricing models (e.g., CAPM or the three-factor Fama-French models). The use of analysts' forecasts does come with a cost, however. Analysts' earnings forecasts potentially have problems that might affect the precision of the cost of capital estimates. For instance, Lys and Sohn [1990] find that analyst short-term earnings forecasts only contain roughly 66\% of the information reflected by security prices prior to the forecast-release date. If analysts do not revise their forecasts in response to recent stock prices changes, which proxy for changes in the overall capital market expectation of future earnings, using those forecasts as inputs in valuation models to estimate the implied cost of capital introduces systematic error into these estimates. These errors are therefore correlated with recent stock price performance. In particular, if analysts' earnings forecasts are slower to reflect revisions in the capital market's expectation than stock prices, then the ex ante implied cost of capital estimate will be too low (high) when recent stock returns have been high (low). ${ }^{29}$

\footnotetext{
${ }^{29}$ The intuition behind this prediction is the following: when earnings forecasts are too low, for example after recent positive stock returns, the implied cost of capital derived from using the current stock price and the present value of future earnings will be too low.
} 
Guay, Kothari and Shu [2003] discuss these problems in detail and report evidence that errors in analysts' earnings forecasts are negatively correlated with recent stock returns. Guay et al. [2003] propose two solutions that address the predictable error in the implied cost of capital estimates: use recent stock returns as a control variable, and estimate the implied cost of capital using different stock prices within a calendar year. To control for the negative correlation between the implied cost of capital estimates and recent stock returns, I re-estimate equation (3a) controlling for RETURN, defined as stock returns measured over the one year period prior to the July $1^{\text {st }}$ measurement date of the implied cost of capital estimate.

The results in Table 7 provide evidence consistent with Guay et al. [2003]'s findings that the OJ implied cost of capital estimate is significantly negatively associated with recent stock returns. However, even after controlling for recent stock returns, the association between the cost of capital estimate and reporting quality squares with the results reported in Table 6, suggesting that financial reporting quality is not significantly associated with the cost of capital.

Guay et al. [2003] also recommend a different estimation procedure for calculating the implied cost of capital, one that allows analysts more time to make use of recent price movements in their earnings forecasts. This procedure estimates the implied cost of capital using the stock price as of January instead of July $1^{\text {st }}$. Although I use this different stock price, I still continue to use analysts' earnings forecasts from June. I report the results of using this alternative implied cost of capital measure in Table 8. This alternative approach does not affect the previously documented results. Controlling for the endogenous character of the reporting quality choice, reporting quality is not significantly associated with a firm's cost of equity capital.

\subsubsection{Reporting Quality and Information Asymmetry}

Table 9 presents the results regarding the association between reporting quality and levels of information asymmetries as proxied by bid-ask spreads. The coefficients of SIZE, VOLUME, and STDRET are both highly significant and consistent with evidence in the extant literature. Table 9 chiefly indicates that higher reporting quality is associated with lower bid-ask spreads.

The results in Columns C and D suggest that higher reporting quality, even after incorporating the endogenous nature of the reporting choice (i.e., using the instrumental 
variables FITQUALITY 1 and FITQUALITY 2 ), leads to significantly lower bid-ask spreads. Consistent with the hypothesis discussed in section 3, providing financial information of higher quality is thus associated with lower levels of perceived information asymmetries. Taken together, the results in this section and the previous one suggest that, although reporting quality may proxy for uncertainty or information risk, this type of firm-specific information risk does not seem to be priced by investors and it does not increase the firm's cost of capital. In other words, the firm-specific uncertainty regarding the estimation of future payoffs does not translate into a higher implied cost of equity capital. This evidence addresses empirical questions raised by Clarkson et al. [1996] regarding the pricing effects of the uncertainty associated with the prediction of future firm-specific payoff parameters.

\subsubsection{Reporting Quality and Analyst Behavior}

As reported in Table 10, after controlling for other determinants of analyst forecast dispersion, all the empirical measures of financial reporting quality display a significant association in the predicted direction with analyst forecast dispersion. This finding suggests that firms choosing to report high-quality financial information enjoy a lower level of dispersion, which implies in turn that investors form more precise beliefs

about future earnings. Interpreting dispersion as a proxy for estimation risk and uncertainty, firms enjoy lower estimation risk by reporting accounting numbers of higher quality. This result is consistent with findings in Lang and Lundholm [1996] who document a negative association between AIMR scores as proxies for firms' disclosure policies and analyst forecast dispersion. The sign and significance of the remaining estimated coefficients in Table 10 (all but SIZE in Columns C and D) tally with findings documented in previous studies (e.g., Piotroski [2003]).

Table 11 reports the results from estimating equation (3d), which addresses the relation between the number of analysts following a firm and the empirical measure of reporting quality, after controlling for other determinants of analysts following. Other than the indicator variable QUALITY, all reporting quality measures display a significant relation with the number of analysts following the firm, which suggests that the number of analysts following a firm increases as the quality of financial information provided in firms' financial statements increases. This result, consistent with previous findings in the literature (Lang and Lundholm [1996]), allows us to infer that the informativeness of a 
firm's information environment increases with the quality of the financial information firms provide. Moreover, this finding is consistent with anecdotal evidence suggesting that financial analysts tend to follow firms that have a more predictable performance stream. The positive significant coefficients both on firm size and firm performance (ROA) are consistent with findings documented in Bhushan [1989].

The evidence on the relation between analysts' behavior and financial reporting quality suggests that by providing high-quality financial information, a firm can both increase the number of the analysts following it, thereby affecting the liquidity of the company's stock (Diamond and Verrecchia [1991]), and reduce its information and estimation risk as proxied by the forecast dispersion (Barry and Brown [1985]).

\section{Conclusion}

This paper provides empirical evidence on the trade-off between capital market valuation benefits and proprietary costs influencing firms' quality of financial reporting decisions. These findings suggest that the variation in firms' financial reporting policies is explained not only by the need to meet investors' demands for firm-specific information, but also by the firm's product market characteristics.

Introducing a new empirical measure of financial reporting quality, I show that the reporting quality choice is positively associated with capital markets benefits and negatively associated with proprietary costs proxies. By accounting for the endogenous nature of the reporting quality decision and thus controlling for firms' corporate disclosure policies choices, I provide evidence that financial reporting quality is associated with lower levels of perceived information asymmetries (as proxied by bid-ask spreads). In addition, financial reporting quality is negatively associated with analyst forecast dispersion and positively associated with the number of analysts following a firm. I do not find, however, a significant negative association between firms' cost of equity capital and financial reporting quality choices, after controlling for known risk factors. These results suggest that reporting quality is not necessarily an additional systematic risk factor, but rather a firm-specific factor associated with uncertainty and estimation precision, which investors do not price.

The results documented in this study contribute to the extant accounting literature in several ways. First, the study contributes to the stream of research analyzing the consequences of financial reporting quality decisions. In particular, the results illustrate 
the importance of explicitly modeling the endogeneity of financial reporting quality choices when investigating the associated economic consequences. Failing to do so may lead to spurious inferences, as indicated by the results. Second, I suggest a reporting quality measure that is easily derived and can be used for a wide range of firms, unlike previous empirical measures, such as analysts' disclosure quality ratings. Finally, this study's findings show the importance of accounting not only for the benefits associated with financial reporting policies, but also for the associated costs. 


\section{Appendix A: Econometric Analysis}

This appendix highlights important econometric issues apparent in empirical disclosure studies.

Assume that we want to estimate the following model using Ordinary Least Squares (OLS):

$\mathrm{Y}_{\mathrm{i}}=\beta^{\prime} \mathrm{X}_{\mathrm{i}}+\theta \mathrm{FQ}_{\mathrm{i}}+\varepsilon_{\mathrm{i}}$

where $Y_{i}$ is the firm's cost of capital proxy, $F_{i}$ is a dummy variable indicating whether firm $\mathrm{i}$ is classified as providing high quality financial information compared to its industry peers, and $\mathrm{X}_{\mathrm{i}}$ represents a set of control variables.

In the empirical tests conducted, the question of interest is whether the coefficient $\theta$ measures the effect of providing high quality financial information on the firm's estimated cost of capital. The answer to this question is no if the typical firm that provides high quality financial information would have a relatively lower cost of capital, i.e., $Y_{i}$ in equation (1) regardless of whether it provided high quality information in its financial statements. If so, then the coefficient $\theta$ will overestimate the treatment effect.

In order to illustrate this point, assume that providing high quality financial information is modeled as:

$\mathrm{FQ}_{\mathrm{i}}^{*}=\omega^{\prime} \mathrm{Z}_{\mathrm{i}}+\eta_{\mathrm{i}}$

where $\mathrm{FQ}_{\mathrm{i}}=1$ if $\mathrm{FQ}_{\mathrm{i}}{ }^{*}>0$, and $\mathrm{FQ}_{\mathrm{i}}=0$ otherwise.

Assume that the typical firm that reports high quality financial information would have a relative low cost of capital regardless of its financial reporting policy. If this is the case, then the errors in the two models, $\varepsilon_{\mathrm{i}}$ and $\eta_{\mathrm{i}}$ are correlated. ${ }^{30}$ Combining the models presented in equation (1) and (2), we get the following (the subscript $\mathrm{i}$ is omitted):

$\mathrm{E}[\mathrm{Y} \mid \mathrm{FQ}=1]=\beta^{\prime} \mathrm{X}+\theta+\mathrm{E}[\varepsilon \mid \mathrm{FQ}=1]=\beta^{\prime} \mathrm{X}+\theta+\rho_{\sigma_{\varepsilon}} \frac{\phi\left(\omega^{\prime} \mathrm{Z}\right)}{\Phi\left(\omega^{\prime} \mathrm{Z}\right)}$

For the low-quality reporting firms, the equivalent equation is:

$\mathrm{E}[\mathrm{Y} \mid \mathrm{FQ}=0]=\beta^{\prime} \mathrm{X}+\rho \sigma_{\varepsilon}\left[\frac{-\phi\left(\omega^{\prime} \mathrm{Z}\right)}{1-\Phi\left(\omega^{\prime} \mathrm{Z}\right)}\right]$

And the difference in expectations is:

\footnotetext{
${ }^{30}$ I assume that the error terms are following a normal distribution. The analysis can be done assuming any other distribution of the error terms.
} 
$\mathrm{E}[\mathrm{Y} \mid \mathrm{FQ}=1]-\mathrm{E}[\mathrm{Y} \mid \mathrm{FQ}=0]=\theta+\rho \sigma_{\varepsilon}\left[\frac{\phi\left(\omega^{\prime} \mathrm{Z}\right)}{\phi\left(\omega^{\prime} \mathrm{Z}\right)\left(1-\Phi\left(\omega^{\prime} \mathrm{Z}\right)\right)}\right]$, where $\phi(\Phi)$ is the normal density function (cumulative density function).

If one does not correct for the selectivity in the original OLS model (equation (1)), the difference presented above is what actually is estimated by the OLS coefficient on the FQ treatment variable. If all terms are positive, then the OLS estimation procedure overestimates the treatment effect, in our case the effect of providing high quality financial information on the firm's cost of capital.

In order to overcome this bias, a selectivity correction can be included in the original OLS equation:

$\lambda=\frac{\phi\left(\omega^{\prime} \mathrm{Z}\right)}{\Phi\left(\omega^{\prime} \mathrm{Z}\right)}$ if $\mathrm{FQ}=1$ or $\lambda=\frac{-\phi\left(\omega^{\prime} \mathrm{Z}\right)}{1-\Phi\left(\omega^{\prime} \mathrm{Z}\right)}$ if $\mathrm{FQ}=0$

This setup is similar to the two-stage procedure introduced by Heckman [1979], but in this case the left hand side variable in equation (1), i.e., the proxy for the firm's cost of capital is observed for all firms. Under this specification, the selectivity correction variable $\lambda$ is an expansion of the Inverse Mills Ratio introduced in the Heckman [1979] procedure, and is equal to the Inverse Mills Ratio when $\mathrm{FQ}=1$.

The model can be estimated either by using Heckman's two-stage estimation procedure which uses the estimates of equation (2) to derive an estimate of the selectivity correction and then include this correction in equation (1) or by other similar approaches. An alternative approach, which I use in the empirical analysis in this study, follows Barnow et al. [1980] and Wooldridge [2002]. Under this approach, the cost of capital model (equation (1)) is estimated using the fitted probabilities of providing high quality financial reporting from a Probit model. The fitted probabilities serve as an instrumental variable for the reporting quality variable. This approach follows from combining the two conditional expectations (for further details see Maddala [1983, p. 121]). This approach holds without assuming a normal distribution for the error terms, which makes it a less restrictive approach compared to Heckman's two-stage procedure. This approach provides consistent estimates using OLS in the second stage estimation of the cost of capital model.

The following illustrates the exact procedure:

Step1: Estimate the binary response model of financial reporting quality choice: 
Prob (FQ=1 $\mid \mathbf{X} \mathbf{Z})$ and obtain the fitted probabilities $\mathrm{FQ}_{\mathrm{i}}$.

Step 2: Estimate equation (1), the cost of capital model by Instrumental Variables (IV) approach using the instruments $\mathrm{FQ}_{\mathrm{i}}$ and $\mathbf{X}$.

Under this estimation procedure, the IV estimator from step 2 is asymptotically efficient.

This procedure has an important property. Since I use $\mathrm{FQ}_{\mathrm{i}}$ as an instrument for $\mathrm{FQ}_{\mathrm{i}}$, the model in the first step, i.e., Prob $(\mathrm{FQ}=1 \mid \mathbf{X} \mathbf{Z})$ does not have to be correctly specified. There is no identification problem in this case even if I do not have an extra exogenous variable excluded from the vector $\mathbf{X}$. Since the fitted probabilities are a nonlinear function of the variables included in the first step probit model, then the second step equation is identified, given this nonlinearity even in the extreme case when $\mathbf{Z}=\mathbf{X}$. However, a caveat is in place: if the first step probability model followed a linear probability model, then the treatment effect $\theta$ would not be identified.

\section{Endogeneity of the Financial Reporting Decision}

Consider again equation (1) introduced above:

$\mathrm{Y}_{\mathrm{i}}=\beta^{\prime} \mathrm{X}_{\mathrm{i}}+\theta \mathrm{FQ}_{\mathrm{i}}+\varepsilon_{\mathrm{i}}$

$\mathrm{FQ}_{\mathrm{i}}$ may be correlated with the error term $\varepsilon_{\mathrm{i}}$, creating a potential econometric problem. This problem can arise due to either measurement error and/or omitted correlated variables. The reason that an omitted correlated variables problem may occur is due to the assertion that financial reporting quality may be a function of determinants which are not captured in the control variables vector X. Given the endogeneity problem, OLS estimation of equation (1) will provide inconsistent estimates of the parameters in equation (1).

To illustrate the consequences of omitting correlated variables from the model specification, consider a revised version of equation (1), which includes an additional variable: W. Assume that W proxies for the competitive position in the firm's product market (W can be a proxy for any identified determinant of financial reporting quality).

$$
\mathrm{Y}_{\mathrm{i}}=\beta^{\prime} \mathrm{X}_{\mathrm{i}}+\theta \mathrm{FQ}_{\mathrm{i}}+\gamma \mathrm{W}_{\mathrm{i}}
$$

Assuming that FQ is not measured with error, an OLS estimation would result in an asymptotically biased estimate: 
$\operatorname{plim} \hat{\theta}=\theta+\gamma \frac{\operatorname{COV}(F Q, W)}{\operatorname{VAR}(F Q)}$. If $\operatorname{COV}(\mathrm{FQ}, \mathrm{W})>0$, implying that firms that provide high quality financial information have also low proprietary costs as proxied by the concentration ratio in their product market, an OLS estimation equation (1) will overestimate $\theta$ as long as $\gamma>0$. One solution to overcome this problem is to use the instrumental variable approach discussed in the first section of the appendix.

\section{Appendix B: Estimating the cost of capital using the Ohlson and Juettner-Nauroth (2000) method}

Consider the following valuation setting as of date 0. Define the following variables/parameters:

$\mathrm{P}_{0} \quad=\quad$ Price per share at date 0 ;

$\mathrm{dps}_{\mathrm{t}}=$ Dividends per share at time $\mathrm{t}$;

eps $_{\mathrm{t}}=$ Earnings per share at time $\mathrm{t}$, and

$\mathrm{R}=1+\mathrm{r}_{\mathrm{e}}$, or $1+$ the cost of equity capital.

Assumption A1: The present value of the expected dividends per share sequence equals price per share:

$$
\mathrm{P}_{0}=\sum_{\mathrm{t}=1}^{\infty} \mathrm{R}^{-\mathrm{t}} \mathrm{dps}_{\mathrm{t}}
$$

Next, Ohlson and Juettner-Nauroth [2000] introduce the following algebraic equation (or identity) into the dividend discount valuation model:

$$
0=y_{0}+\left(\frac{y_{1}-R y_{0}}{R}\right)+\left(\frac{y_{2}-R y_{1}}{R^{2}}\right)+\ldots
$$

Where $\left\{y_{t}\right\}_{t=0}^{\infty}$ can be any sequence of numbers that satisfy the following condition: $R^{-T} y_{T} \rightarrow 0$ as $T \rightarrow \infty$.

Equation (2) holds because $\mathrm{y}_{0}+\sum_{\mathrm{t}=1}^{\mathrm{T}} \mathrm{R}^{-\mathrm{t}}\left(\mathrm{y}_{\mathrm{t}}-\mathrm{R} \mathrm{y}_{\mathrm{t}-1}\right)=\mathrm{R}^{-\mathrm{T}} \mathrm{y}_{\mathrm{T}}$

Adding equation (1) and equation (2) yields:

$$
\mathrm{P}_{0}=\mathrm{y}_{0}+\sum_{\mathrm{t}=1}^{\infty}\left(\frac{\mathrm{y}_{\mathrm{t}}+\mathrm{dps}_{\mathrm{t}}-\mathrm{Ry}_{\mathrm{t}-1}}{\mathrm{R}}\right)
$$

In order to introduce growth in the model, Equation (3) can be expressed as: 
$\mathrm{P}_{0}=\frac{\mathrm{eps}_{1}}{\mathrm{r}_{\mathrm{e}}}+\sum_{\mathrm{t}=1}^{\infty}\left(\frac{\mathrm{z}_{\mathrm{t}}}{\mathrm{R}}\right)$

Where: $\mathrm{y}_{0}=\mathrm{eps}_{1} / \mathrm{r}_{\mathrm{e}} ; \quad \mathrm{y}_{\mathrm{t}}=\mathrm{eps}_{\mathrm{t}+1} / \mathrm{r}_{\mathrm{e}} ;$ and $\quad \mathrm{z}_{\mathrm{t}} \equiv \frac{1}{\mathrm{r}_{\mathrm{e}}}\left(\mathrm{eps}_{\mathrm{t}+1}+\mathrm{r}_{\mathrm{e}} \mathrm{dps}_{\mathrm{t}}-\mathrm{R} * \mathrm{eps}_{\mathrm{t}}\right)$

Assuming that the sequence $\left\{z_{t}\right\}_{t=0}^{\infty}$ satisfies $z_{t+1}=\gamma z_{t}$ for all $\mathrm{t}$, where $1 \leq \gamma<R$ and $\mathrm{z}_{1}>0$, we get:

$P_{0}=\frac{e p s_{1}}{r_{e}}+\frac{z_{1}}{R-\gamma}$

where $\mathrm{z}_{1} \equiv \frac{1}{\mathrm{r}_{\mathrm{e}}}\left(\mathrm{eps}_{2}+\mathrm{r}_{\mathrm{e}} \mathrm{dps}_{1}-\mathrm{R} * \mathrm{eps}_{1}\right)$

Solving equation (5) for the implied cost of equity capital $r_{e}$, yields:

$$
r_{e}=A+\sqrt{A^{2}+\frac{e^{e p s}}{P_{0}} *\left(\frac{\Delta \mathrm{eps}_{2}}{\mathrm{eps}_{1}}-(\gamma-1)\right)}
$$

where: $\quad \mathrm{A} \equiv \frac{1}{2}\left(\gamma-1+\frac{\mathrm{dps}_{1}}{\mathrm{P}_{0}}\right)$, and $\Delta \mathrm{eps}_{2}=\mathrm{eps}_{2}-\mathrm{eps}_{1}$

In order to obtain firm-year estimates of $r_{e}$, I use equation (6), assuming that $\gamma-1$ equals $r_{f}-3 \%$, where $r_{f}$ is the yield on 10-year notes (Gode and Mohanram [2002]). I use the current dividend payout ratio as an estimate of $\mathrm{dps}_{1}$ (Compustat annual data item \#26) and obtain eps ${ }_{1}$ and eps $_{2}$ from the Zacks database. Firms which have annual earnings forecasts from Zacks that are negative must be eliminated from the sample, consistent with the assumption that $\mathrm{z}_{1}>0$. 
Table 1: Variable Definitions

\begin{tabular}{|c|c|}
\hline EARN & $\begin{array}{l}\text { Income before extraordinary items and discontinued operations (Compustat annual item \#18). } \\
\end{array}$ \\
\hline CFO & $\begin{array}{l}\text { Cash flow from operations (Compustat annual data item \#308) minus the accrual portion of extraordinary } \\
\text { items and discontinued operations per the statement of cash flows (Compustat annual data item \#124). }\end{array}$ \\
\hline$\Delta \mathrm{AR}$ & Change in accounts receivable account per statement of cash flows (Compustat annual data item \#302). \\
\hline$\Delta \mathrm{INV}$ & Change in inventory account per the statement of cash flows (Compustat annual data item \#303). \\
\hline$\triangle A P$ & $\begin{array}{l}\text { Change in accounts payable and accrued liabilities account per the statement of cash flows (Compustat annual } \\
\text { data item \#304). }\end{array}$ \\
\hline DEPR & Depreciation and Amortization Expense (Compustat annual data item \#125). \\
\hline OTHER & Net of all other accruals, calculated as EARN - (CFO $+\Delta$ AR $+\Delta$ INV- $\Delta$ AP-DEPR). \\
\hline RES & $\begin{array}{l}\text { The absolute value of residuals obtained from a regression of future operating cash flows on current operating } \\
\text { cash flows and accrual components. }\end{array}$ \\
\hline SIZE & $\begin{array}{l}\text { Natural logarithm of market capitalization at the end of the fiscal year, calculated as the closing price at fiscal } \\
\text { year-end times the number of shares outstanding at fiscal year-end (Compustat annual data item \#199 times } \\
\text { Compustat annual data item \#25). }\end{array}$ \\
\hline QUALITY & An indicator variable equal to one if RES is less than the Industry median RES, and zero otherwise. \\
\hline ASSETS & Total assets (Compustat annual data item \#6). \\
\hline ROA & $\begin{array}{l}\text { Return on assets, defined as EARN (Compustat annual data item \#18) divided by total assets (Compustat } \\
\text { annual data item \#6). }\end{array}$ \\
\hline B_M & $\begin{array}{l}\text { Book-to-Market ratio, where the book value of common equity (Compustat annual data item \#60) is divided } \\
\text { by market value of equity (calculated as the closing price at fiscal year-end times the number of shares } \\
\text { outstanding at fiscal year-end (Compustat annual data item \#199 times Compustat annual data item \#25)). }\end{array}$ \\
\hline GROWTH & $\begin{array}{l}\text { Current year's growth in sales, calculated as net sales for year t (Compustat annual data item \#12) less net } \\
\text { sales of year t-1, scaled by net sales for year } \mathrm{t}-1 \text {. }\end{array}$ \\
\hline E_GROWTH & $\begin{array}{l}\text { Expected long term growth in earnings, defined as the percentage change in the mean two-year ahead earnings } \\
\text { forecast (obtained from Zacks) from the current earnings realization (Compustat annual data item \#58). }\end{array}$ \\
\hline HERF & $\begin{array}{l}\text { The Herfindahl Index is calculated as the sum of squares of market shares in the industry: } \\
H E R F=\sum_{i=1}^{n}\left[s_{i} / S\right]^{2} \text {, where } S_{i} \text { is the firm's sales and } \mathrm{S} \text { is the sum of sales for all firms in the industry } \\
\text { (defined by the two-digit SIC code), and } \mathrm{n} \text { is the number of firms in the industry. }\end{array}$ \\
\hline LEVERAGE & $\begin{array}{l}\text { Long term debt (Compustat annual data item \#9) plus debt in current liabilities (Compustat annual data item } \\
\# 34 \text { ) divided by total assets (Compustat annual data item \#6). }\end{array}$ \\
\hline CAPITAL & $\begin{array}{l}\text { Net plant, property and equipment (Compustat annual data item \#8) divided by total assets (Compustat annual } \\
\text { data item \#6). }\end{array}$ \\
\hline OC & Operating Cycle (in days), calculated as $\frac{\left(A R_{t}+A R_{t-1}\right) / 2}{(\text { Sales } / 360)}+\frac{\left(I N V_{t}+I N V_{t-1}\right) / 2}{(C O G S / 360)}$. \\
\hline N_SEG & Number of two-digit SIC code industries that the firm is engaged in. \\
\hline MARGIN & $\begin{array}{l}\text { Gross margin percentage, calculated as the year t net sales (Compustat annual data item \#12) less cost of } \\
\text { goods sold for the year (Compustat annual data item \#41), scaled by net sales. }\end{array}$ \\
\hline E_P RATIO & $\begin{array}{l}\text { Industry-adjusted earnings-price ratio. Annual earnings per share before discontinued operations and } \\
\text { extraordinary items (Compustat annual item \#58) divided by the July } 1^{\text {st }} \text { price. }\end{array}$ \\
\hline $\mathrm{R}_{\mathrm{e}}$ & Cost of equity capital estimated from the Ohlson and Juettner-Nauroth [2000] model. \\
\hline DISP & Standard Deviation of analysts' forecasts of earnings per share, scaled by the beginning of the period price. \\
\hline SPREAD & $\begin{array}{l}\text { Mean daily bid-ask spread scaled by the midpoint of the spread, averaged over the } 12 \text { months starting } \\
\text { as of June subsequent to fiscal year t. }\end{array}$ \\
\hline VOLUME & $\begin{array}{l}\text { Natural logarithm of the daily number of shares traded averaged over the } 12 \text { months starting as of June } \\
\text { subsequent to fiscal year t. }\end{array}$ \\
\hline STDRET & $\begin{array}{l}\text { Standard deviation of daily holding period return averaged over the } 12 \text { months starting as of June } \\
\text { subsequent to fiscal year t. }\end{array}$ \\
\hline LIST & $\begin{array}{l}\text { A dummy variable which equals } 1 \text { if the firm was listed on NASDAQ over the corresponding period and zero } \\
\text { otherwise. }\end{array}$ \\
\hline EPS & $\begin{array}{l}\text { Earnings per share before discontinued operations and extraordinary items (Compustat annual data item \#58) } \\
\text { adjusted for stock splits and dividends. }\end{array}$ \\
\hline ANALYST & Number of analysts making EPS forecasts for firm i at the time DISP is calculated (data obtained from Zacks). \\
\hline BETA & $\begin{array}{l}\text { The market beta for firm i in year t, estimated using a rolling window of five years of monthly returns where } \\
\text { the CRSP weighted market return is used as the market return. }\end{array}$ \\
\hline SURP & $\begin{array}{l}\text { Absolute value of the difference between current year's earnings per share (Compustat annual data item \#58) } \\
\text { and the previous year earnings per share. }\end{array}$ \\
\hline OWNER & $\begin{array}{l}\text { Natural log of the number of shareholders of a firm (Compustat item \#100) minus the natural log of median } \\
\text { number of shareholders is same two-digit SIC code. }\end{array}$ \\
\hline
\end{tabular}


Table 2

Descriptive Statistics

This table presents descriptive statistics for the total sample of 16,664 firm-year observations.

Variables are defined in Table 1.

\begin{tabular}{||l|c|c|c||}
\hline VARIABLE & MEAN & MEDIAN & STD. DEV. \\
\hline SIZE (\$mil) & & & \\
\hline ASSETS (\$mil) & 1848.71 & 262.23 & 5215.11 \\
\hline ROA & 1799.75 & 288.12 & 4066.49 \\
\hline RES & 0.034 & 0.042 & 0.118 \\
\hline GROWTH & 0.055 & 0.036 & 0.064 \\
\hline HERF & 0.089 & 0.073 & 0.275 \\
\hline LEVERAGE & 0.273 & 0.246 & 0.118 \\
\hline OC (days) & 0.187 & 0.168 & 0.163 \\
\hline N_SEG & 136.12 & 122.70 & 75.70 \\
\hline$R_{e}$ & 2.64 & 1.00 & 2.73 \\
\hline SPREAD & 0.128 & 0.108 & 0.076 \\
\hline DISP & 0.0371 & 0.0325 & 0.0202 \\
\hline ANALYST & 0.0129 & 0.0054 & 0.046 \\
\hline \hline
\end{tabular}


Table 3

\section{Correlation Matrix of Financial Reporting Quality Determinants}

This table reports Pearson (above the diagonal) and Spearman correlations (below the diagonal). The sample is based on 16,664 firmyear observations.

Variables are defined in Table 1.

\begin{tabular}{||l|c|c|c|c|c|c|c|c|c|c||}
\hline & QUALITY & OWNER & MARGIN & HERF & GROWTH & CAPITAL & SIZE & LEVERAGE & OC & N_SEG \\
\hline QUALITY & & $0.193^{*}$ & $-0.123^{*}$ & $-0.144^{*}$ & $-0.093^{* *}$ & $0.151^{*}$ & $0.055^{*}$ & $0.073^{*}$ & $-0.019^{*}$ & $0.061^{*}$ \\
\hline OWNER & $0.236^{*}$ & & $-0.024^{*}$ & $-0.057^{*}$ & $-0.155^{*}$ & $0.321^{*}$ & $0.487^{*}$ & $0.185^{*}$ & $-0.159^{*}$ & $0.281^{*}$ \\
\hline MARGIN & $-0.091^{*}$ & $-0.032^{*}$ & & $-0.094^{*}$ & 0.010 & $-0.041^{*}$ & $0.091^{*}$ & $-0.170^{*}$ & $0.311^{*}$ & $-0.118^{*}$ \\
\hline HERF & $-0.023^{*}$ & $-0.031^{*}$ & $-0.081^{*}$ & & 0.004 & -0.008 & $-0.023^{*}$ & $0.032^{* *}$ & $0.018^{* *}$ & 0.011 \\
\hline GROWTH & $-0.154^{*}$ & $-0.081^{*}$ & $0.027^{*}$ & -0.005 & & $-0.015^{* *}$ & $-0.03^{*}$ & $-0.07^{*}$ & -0.002 & $-0.11^{* *}$ \\
\hline CAPITAL & $0.302^{*}$ & $0.310^{*}$ & $-0.051^{* *}$ & 0.003 & $-0.027^{* *}$ & & $0.478^{*}$ & $0.191^{*}$ & $-0.019^{*}$ & $0.234^{*}$ \\
\hline SIZE & $0.158^{*}$ & $0.429^{*}$ & $0.137^{*}$ & 0.019 & $-0.021^{* *}$ & $0.356^{*}$ & & 0.0023 & $-0.13^{*}$ & $0.309^{*}$ \\
\hline LEVERAGE & $0.097^{*}$ & $0.186^{*}$ & $-0.209^{*}$ & $0.08^{*}$ & -0.004 & $0.200^{*}$ & $0.121^{*}$ & & $-0.021^{*}$ & $0.165^{*}$ \\
\hline OC & $-0.014^{* *}$ & $-0.152^{*}$ & $0.371^{*}$ & $-0.09^{*}$ & $-0.053^{*}$ & $-0.175^{*}$ & -0.001 & $-0.017^{*}$ & & -0.042 \\
\hline N_SEG & $0.012^{*}$ & $0.209^{*}$ & $-0.084^{* *}$ & 0.017 & -0.01 & $0.181^{*}$ & $0.203^{*}$ & $0.112^{*}$ & $-0.023^{*}$ & \\
\hline \hline
\end{tabular}

**,* - Correlation significant at the 5\%, $1 \%$ level, respectively. 


\section{Table $4^{\mathrm{a}}$}

\section{Probit Analysis of the Determinants of Firms' Financial Reporting Quality}

Probit analysis of the determinants of firms' financial reporting quality. The binary dependent variable is equal to 1 if RES < Industry Median RES, where RES is the absolute value of the residuals obtained from the following industry regression estimated for each year $t$ for each two-digit SIC code:

$$
\mathrm{CFO}_{\mathrm{i}, \mathrm{t}+1}=\alpha_{0}+\beta_{1} \mathrm{CFO}_{\mathrm{i}, \mathrm{t}}+\beta_{2} \Delta \mathrm{AR}_{\mathrm{i}, \mathrm{t}}+\beta_{3} \Delta \mathrm{INV}_{\mathrm{i}, \mathrm{t}}+\beta_{4} \Delta \mathrm{AP}_{\mathrm{i}, \mathrm{t}}+\beta_{5} \mathrm{DEPR}_{\mathrm{i}, \mathrm{t}}+\beta_{6} \mathrm{OTHER}_{\mathrm{i}, \mathrm{t}}+\varepsilon_{\mathrm{i}, \mathrm{t}+1}
$$

All the variables in this table are defined in Table 1.

$$
\begin{aligned}
& \text { QUALITY }_{\mathrm{i}, \mathrm{t}+1}=\phi_{0}+\phi_{1} \text { OWNER }_{\mathrm{i}, \mathrm{t}}+\phi_{2} \text { GROWTH }_{\mathrm{i}, \mathrm{t}}+\phi_{3} \text { CAPITAL }_{\mathrm{i}, \mathrm{t}}+\phi_{4} \text { HERF }_{\mathrm{i}, \mathrm{t}} \\
& \phi_{5} \text { LEVERAGE }_{\mathrm{i}, \mathrm{t}}+\phi_{6} \text { MARGIN }_{\mathrm{i}, \mathrm{t}}+\phi_{7} \mathrm{OC}_{\mathrm{i}, \mathrm{t}}+\phi_{8} \mathrm{~N}_{-} \text {SEG }_{\mathrm{i}, \mathrm{t}}+\phi_{9} \mathrm{SIZE}_{\mathrm{i}, \mathrm{t}}+\xi_{\mathrm{i}, \mathrm{t}+1}
\end{aligned}
$$

\begin{tabular}{||l|c|c|c||}
\hline VARIABLE & PREDICTION & $\begin{array}{c}\text { COEFFICIENT } \\
\text { (P-VALUE) }\end{array}$ & $\begin{array}{c}\text { MARGINAL } \\
\text { PROB. }\end{array}$ \\
\hline OWNER & + & $\begin{array}{c}0.714^{* * *} \\
(0.000)\end{array}$ & 0.086 \\
\hline GROWTH & - & $\begin{array}{c}-0.023 \\
(0.211)\end{array}$ & -0.002 \\
\hline CAPITAL & + & $\begin{array}{c}0.00002^{* * *} \\
(0.000)\end{array}$ & 0.032 \\
\hline HERF & $+/-$ & $\begin{array}{c}-0.185^{* * *} \\
(0.000)\end{array}$ & -0.022 \\
\hline LEVERAGE & + & $0.523^{* * *}$ & 0.130 \\
& & $(0.000)$ & -0.031 \\
\hline MARGIN & $+/-$ & $-0.331^{* * *}$ & $(0.005)$ \\
\hline OC & - & $-0.0005^{* *}$ & -0.030 \\
& & $(0.032)$ & -0.013 \\
\hline N_SEG & $+/-$ & $\left(0.081^{*}\right.$ & 0.019 \\
\hline SIZE & + & $0.002^{* *}$ & \\
\hline & & $(0.037)$ & \\
\hline Psuedo R ${ }^{2}$ & & $14.45 \%$ & \\
\hline \hline
\end{tabular}

***,**,* - Correlation significant at the 1\%, 5\%,10\% level, respectively.

\footnotetext{
${ }^{a}$ This table provides the results from estimating equation (2) for the sample firms. For each variable in the table, the estimated coefficient, the marginal probability, and the p-value are provided. The marginal probability represents the change in the probability of providing high quality financial information for a one standard deviation change in the independent variable of interest.
} 
Table 5

Consequences of Financial Reporting Quality: Association between Industry-
Adjusted E/P Ratio and Reporting Quality

$E_{-} P_{i, t+\tau}=\delta_{0}+\delta_{1} E_{-} G R O W T H_{i, t}+\delta_{2} L E V E R A G E_{i, t}+\delta_{3} \operatorname{SIZE}_{i, t}+\delta_{4} B_{-} M_{i, t}+\delta_{5} F Q_{i, t}+v_{i, t+\tau}$

\begin{tabular}{|c|c|c|c|c|}
\hline & FQ = QUALITY & $\begin{array}{l}\text { FQ=ADJ_RES } \\
\end{array}$ & $\overline{\text { FQ=FITQUALITY }}$ & $\overline{\text { FQ=FITQUALITY }} 2$ \\
\hline VARIABLE & $\begin{array}{l}\text { Coefficient } \\
\text { (t-statistic) }\end{array}$ & $\begin{array}{l}\text { Coefficient } \\
\text { (t-statistic) }\end{array}$ & $\begin{array}{l}\text { Coefficient } \\
\text { (t-statistic) }\end{array}$ & $\begin{array}{l}\text { Coefficient } \\
\text { (t-statistic) }\end{array}$ \\
\hline E_GROWTH & $\begin{array}{c}-0.011 \\
(-9.29)^{* * *}\end{array}$ & $\begin{array}{c}-0.011 \\
(-9.64)^{* * *}\end{array}$ & $\begin{array}{c}-0.011 \\
(-9.95)^{* * *}\end{array}$ & $\begin{array}{c}-0.011 \\
(-9.76)^{* * *}\end{array}$ \\
\hline LEVERAGE & $\begin{array}{c}0.0156 \\
(3.82)^{* * *}\end{array}$ & $\begin{array}{c}0.0180 \\
(4.23)^{* * *}\end{array}$ & $\begin{array}{c}0.0066 \\
(0.90)\end{array}$ & $\begin{array}{c}0.0177 \\
(2.72)^{* *}\end{array}$ \\
\hline SIZE & $\begin{array}{c}-0.0130 \\
(-9.78) * * *\end{array}$ & $\begin{array}{c}-0.0130 \\
(-9.89) * * *\end{array}$ & $\begin{array}{c}-0.0130 \\
(-9.75)^{* * *}\end{array}$ & $\begin{array}{c}-0.0130 \\
(-9.80)^{* * *}\end{array}$ \\
\hline B_M & $\begin{array}{c}0.0066 \\
(8.99)^{* * *}\end{array}$ & $\begin{array}{c}0.0068 \\
(9.04)^{* * *}\end{array}$ & $\begin{array}{c}0.0057 \\
(6.68)^{* * *}\end{array}$ & $\begin{array}{c}0.0066 \\
(8.54)^{* * *}\end{array}$ \\
\hline QUALITY & $\begin{array}{c}-0.0022 \\
(-3.59) * * *\end{array}$ & & & \\
\hline ADJ_RES & & $\begin{array}{c}0.1015 \\
(6.09)^{* * *}\end{array}$ & & \\
\hline FITQUALITY $_{1}$ & & & $\begin{array}{l}-0.0327 \\
(-1.62)\end{array}$ & \\
\hline FITQUALITY $_{2}$ & & & & $\begin{array}{l}0.0947 \\
(0.79)\end{array}$ \\
\hline Mean Adj. $\mathbf{R}^{2}$ & 0.1425 & 0.1555 & 0.1543 & 0.1553 \\
\hline
\end{tabular}

$* * *, * *, *$ Statistical significance at the $1 \%, 5 \%, 10 \%$ level (two-tailed test). The t-statistics are reported in parentheses.

$\mathrm{RES}_{\mathrm{i}, \mathrm{t}}$ is equal to the absolute value of the residuals obtained from the following industry regression estimated for each year $\mathrm{t}$ for each two-digit SIC code:

$\mathrm{CFO}_{\mathrm{i}, \mathrm{t}+1}=\alpha_{0}+\beta_{1} \mathrm{CFO}_{\mathrm{i}, \mathrm{t}}+\beta_{2} \Delta \mathrm{AR}_{\mathrm{i}, \mathrm{t}}+\beta_{3} \Delta \mathrm{INV}_{\mathrm{i}, \mathrm{t}}+\beta_{4} \Delta \mathrm{AP}_{\mathrm{i}, \mathrm{t}}+\beta_{5} \mathrm{DEPR}_{\mathrm{i}, \mathrm{t}}+\beta_{6} \mathrm{OTHER}_{\mathrm{i}, \mathrm{t}}+\varepsilon_{\mathrm{i}, \mathrm{t}+1}$

$\mathrm{FQ}_{\mathrm{i}, \mathrm{t}}$ - Financial reporting quality measure:

QUALITY: Indicator variable equal to one if $\mathrm{RES}_{\mathrm{i}, \mathrm{t}}<$ industry median RES.

ADJ_RES: Industry-adjusted $\mathrm{RES}_{\mathrm{i}, \mathrm{t}}$.

FITQUALITY $_{1}$ : Instrumental variable which is equal to the fitted probabilities obtained from a Probit estimation, where the dependent variable is QUALITY.

FITQUALITY $_{2}$ : Instrumental variable which is equal to the fitted value obtained from an OLS regression, where the dependent variable is ADJ_RES.

Table 5 reports mean coefficients and corresponding t-statistics (corrected for serial-correlation) from yearly OLS regressions. 


\section{Table 6}

\section{Consequences of Financial Reporting Quality: Association between Firm-Specific Cost of Capital and Reporting Quality}

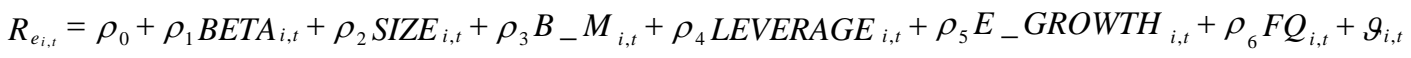

\begin{tabular}{|c|c|c|c|c|}
\hline & "FQ = QUALITY & "FQ=ADJ_RES & FQ=FITQUALITY & FQ=FITQUALITY 2 \\
\hline VARIABLE & $\begin{array}{l}\text { Coefficient } \\
\text { (t-statistic) }\end{array}$ & $\begin{array}{l}\text { Coefficient } \\
\text { (t-statistic) }\end{array}$ & $\begin{array}{l}\text { Coefficient } \\
\text { (t-statistic) }\end{array}$ & $\begin{array}{l}\text { Coefficient } \\
\text { (t-statistic) }\end{array}$ \\
\hline BETA & $\begin{array}{c}0.0042 \\
(2.25)^{* * *}\end{array}$ & $\begin{array}{c}0.0041 \\
(2.20)^{* *}\end{array}$ & $\begin{array}{c}0.0045 \\
(2.55)^{* * *}\end{array}$ & $\begin{array}{c}0.0034 \\
(1.71)\end{array}$ \\
\hline SIZE & $\begin{array}{c}-0.0390 \\
(-11.77)^{* * *}\end{array}$ & $\begin{array}{c}-0.0390 \\
(-11.89)^{* * *}\end{array}$ & $\begin{array}{c}-0.0370 \\
(-15.38)^{* * *}\end{array}$ & $\begin{array}{c}-0.0370 \\
(-15.50)^{* * *}\end{array}$ \\
\hline$\overline{\text { B_M }}$ & $\begin{array}{c}0.0214 \\
(8.98)^{* * *}\end{array}$ & $\begin{array}{c}0.0217 \\
(9.20)^{* * *}\end{array}$ & $\begin{array}{c}0.0191 \\
(11.67)^{* * *}\end{array}$ & $\begin{array}{c}0.2020 \\
(11.58)^{* * *}\end{array}$ \\
\hline LEVERAGE & $\begin{array}{c}0.0472 \\
(6.76)^{* * *}\end{array}$ & $\begin{array}{c}0.0477 \\
(6.77)^{* * *}\end{array}$ & $\begin{array}{c}0.0307 \\
(5.04)^{* * *}\end{array}$ & $\begin{array}{c}0.0446 \\
(7.54)^{* * *}\end{array}$ \\
\hline E_GROWTH & $\begin{array}{c}0.0155 \\
(5.38)^{* * *}\end{array}$ & $\begin{array}{c}0.0157 \\
(5.67)^{* * *}\end{array}$ & $\begin{array}{c}0.0159 \\
(5.76)^{* * *}\end{array}$ & $\begin{array}{c}0.0161 \\
(5.85)^{* * *}\end{array}$ \\
\hline QUALITY & $\begin{array}{c}-0.0034 \\
(-2.43)^{* *}\end{array}$ & & & \\
\hline ADJ_RES & & $\begin{array}{c}0.0380 \\
(3.19)^{* * *}\end{array}$ & & \\
\hline FITQUALITY $_{1}$ & & & $\begin{array}{c}-0.0544 \\
(-1.66)\end{array}$ & \\
\hline FITQUALITY $_{2}$ & & & & $\begin{array}{c}0.0435 \\
(0.19)\end{array}$ \\
\hline Mean Adj. $\mathrm{R}^{2}$ & 0.2832 & 0.2835 & 0.2917 & 0.2906 \\
\hline
\end{tabular}

$* * *, * *, *$ Statistical significance at the $1 \%, 5 \%, 10 \%$ level (two-tailed test). The t-statistics are reported in parentheses.

$\mathrm{RES}_{\mathrm{i}, \mathrm{t}}$ is equal to the absolute value of the residuals obtained from the following industry regression estimated for each year $t$ for each two-digit SIC code:

$\mathrm{CFO}_{\mathrm{i}, \mathrm{t}+1}=\alpha_{0}+\beta_{1} \mathrm{CFO}_{\mathrm{i}, \mathrm{t}}+\beta_{2} \Delta \mathrm{AR}_{\mathrm{i}, \mathrm{t}}+\beta_{3} \Delta \mathrm{INV}_{\mathrm{i}, \mathrm{t}}+\beta_{4} \Delta \mathrm{AP}_{\mathrm{i}, \mathrm{t}}+\beta_{5} \mathrm{DEPR}_{\mathrm{i}, \mathrm{t}}+\beta_{6} \mathrm{OTHER}_{\mathrm{i}, \mathrm{t}}+\varepsilon_{\mathrm{i}, \mathrm{t}+1}$

$\mathrm{FQ}_{\mathrm{i}, \mathrm{t}}-$ Financial reporting quality measure:

QUALITY: Indicator variable equal to one if $\mathrm{RES}_{\mathrm{i}, \mathrm{t}}<$ industry median RES.

ADJ_RES: Industry-adjusted RES $\mathrm{i}_{\mathrm{i}, \mathrm{t}}$.

FITQUALITY $_{1}$ : Instrumental variable which is equal to the fitted probabilities obtained from a Probit estimation, where the dependent variable is QUALITY.

FITQUALITY $_{2}$ : Instrumental variable which is equal to the fitted value obtained from an OLS regression, where the dependent variable is ADJ_RES.

Table 6 reports mean coefficients and corresponding t-statistics (corrected for serial-correlation) from yearly OLS regressions. 


\section{Table 7}

\section{Consequences of Financial Reporting Quality: Association between Firm-Specific Cost of Capital and Reporting Quality}

$$
R_{e_{i, t}}=\rho_{0}+\rho_{1} \text { BETA }_{i, t}+\rho_{2} \operatorname{SIZE}_{i, t}+\rho_{3} B_{-} M_{i, t}+\rho_{4} \operatorname{LEVERAGE}_{i, t}+\rho_{5} E_{-} \operatorname{GROWTH}_{i, t}+\rho_{6} \operatorname{RETURN}_{i, t}+\rho_{7} F Q_{i, t}+\vartheta_{i, t}
$$

\begin{tabular}{|c|c|c|c|c|}
\hline & 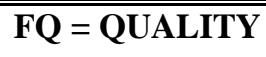 & $\begin{array}{l}\text { FQ=ADJ_RES } \\
\end{array}$ & 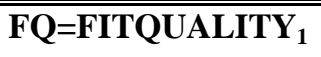 & 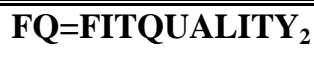 \\
\hline VARIABLE & $\begin{array}{l}\text { Coefficient } \\
\text { (t-statistic) }\end{array}$ & $\begin{array}{l}\text { Coefficient } \\
\text { (t-statistic) }\end{array}$ & $\begin{array}{l}\text { Coefficient } \\
\text { (t-statistic) }\end{array}$ & $\begin{array}{l}\text { Coefficient } \\
\text { (t-statistic) }\end{array}$ \\
\hline BETA & $\begin{array}{c}0.0054 \\
(3.39)^{* * *}\end{array}$ & $\begin{array}{c}0.0051 \\
(3.30)^{* * *}\end{array}$ & $\begin{array}{c}0.0045 \\
(2.85)^{* *}\end{array}$ & $\begin{array}{c}0.0043 \\
(2.66)^{* *}\end{array}$ \\
\hline SIZE & $\begin{array}{c}-0.360 \\
(-10.55)^{* * *}\end{array}$ & $\begin{array}{c}-0.0360 \\
(-10.37)^{* * *}\end{array}$ & $\begin{array}{c}-0.0340 \\
(-13.65)^{* * *}\end{array}$ & $\begin{array}{c}-0.0340 \\
(-13.46)^{* * *}\end{array}$ \\
\hline$\overline{\text { B_M }}$ & $\begin{array}{c}0.0196 \\
(7.95)^{* * *}\end{array}$ & $\begin{array}{c}0.0198 \\
(7.83)^{* * *}\end{array}$ & $\begin{array}{c}0.0185 \\
(9.00)^{* * *}\end{array}$ & $\begin{array}{c}0.0186 \\
(9.34)^{* * *}\end{array}$ \\
\hline LEVERAGE & $\begin{array}{c}0.0457 \\
(6.79)^{* * * *}\end{array}$ & $\begin{array}{c}0.0483 \\
(6.50)^{* * *}\end{array}$ & $\begin{array}{c}0.0426 \\
(6.12)^{* * *}\end{array}$ & $\begin{array}{c}0.0445 \\
(6.58)^{* * *}\end{array}$ \\
\hline E_GROWTH & $\begin{array}{c}0.0151 \\
(5.58)^{* * *}\end{array}$ & $\begin{array}{c}0.0150 \\
(5.80)^{* * *}\end{array}$ & $\begin{array}{c}0.0155 \\
(5.83)^{* * *}\end{array}$ & $\begin{array}{c}0.0154 \\
(5.75)^{* * *}\end{array}$ \\
\hline RETURN & $\begin{array}{c}-0.0210 \\
(-5.33) * * *\end{array}$ & $\begin{array}{c}-0.0220 \\
(-5.54) * * *\end{array}$ & $\begin{array}{c}-0.0230 \\
(-5.56) * * *\end{array}$ & $\begin{array}{c}-0.0230 \\
(-5.76) * * *\end{array}$ \\
\hline QUALITY & $\begin{array}{c}-0.0045 \\
(-3.45)^{* * *}\end{array}$ & & & \\
\hline ADJ_RES & & $\begin{array}{c}0.1445 \\
(4.08)^{* * *}\end{array}$ & & \\
\hline FITQUALITY $_{1}$ & & & $\begin{array}{c}-0.0115 \\
(-0.74) \\
\end{array}$ & \\
\hline FITQUALITY $_{2}$ & & & & $\begin{array}{l}0.1587 \\
(1.49) \\
\end{array}$ \\
\hline Mean Adj. $\mathbf{R}^{2}$ & 0.2903 & 0.2913 & 0.2912 & 0.2907 \\
\hline
\end{tabular}

***, **, * Statistical significance at the 1\%, 5\%, 10\% level (two-tailed test). The t-statistics are reported in parentheses.

$\mathrm{RES}_{\mathrm{i}, \mathrm{t}}$ is equal to the absolute value of the residuals obtained from the following industry regression estimated for each year $t$ for each two-digit SIC code:

$\mathrm{CFO}_{\mathrm{i}, \mathrm{t}+1}=\alpha_{0}+\beta_{1} \mathrm{CFO}_{\mathrm{i}, \mathrm{t}}+\beta_{2} \Delta \mathrm{AR}_{\mathrm{i}, \mathrm{t}}+\beta_{3} \Delta \mathrm{INV}_{\mathrm{i}, \mathrm{t}}+\beta_{4} \Delta \mathrm{AP}_{\mathrm{i}, \mathrm{t}}+\beta_{5} \mathrm{DEPR}_{\mathrm{i}, \mathrm{t}}+\beta_{6} \mathrm{OTHER}_{\mathrm{i}, \mathrm{t}}+\varepsilon_{\mathrm{i}, \mathrm{t}+1}$

$\mathrm{FQ}_{\mathrm{i}, \mathrm{t}}-$ Financial reporting quality measure:

QUALITY: Indicator variable equal to one if $\mathrm{RES}_{\mathrm{i}, \mathrm{t}}<$ industry median RES.

ADJ_RES: Industry-adjusted $\mathrm{RES}_{\mathrm{i}, \mathrm{t}}$.

FITQUALITY $_{1}$ : Instrumental variable which is equal to the fitted probabilities obtained from a Probit estimation, where the dependent variable is QUALITY.

FITQUALITY $_{2}$ : Instrumental variable which is equal to the fitted value obtained from an OLS regression, where the dependent variable is ADJ_RES.

RETURN: the stock return measured from July to June during the one-year period over which the implied cost of capital is measured.

Table 7 reports mean coefficients and corresponding t-statistics (corrected for serial-correlation) from yearly OLS regressions. 


\section{Table 8}

\section{Consequences of Financial Reporting Quality: Association between Firm-Specific Cost of Capital and Reporting Quality}

$$
R_{e_{i, t}}=\rho_{0}+\rho_{1} \text { BETA }_{i, t}+\rho_{2} \operatorname{SIZE}_{i, t}+\rho_{3} B_{-} M_{i, t}+\rho_{4} \text { LEVERAGE }_{i, t}+\rho_{5} E_{-} G R O W T H_{i, t}+\rho_{6} F Q_{i, t}+\vartheta_{i, t}
$$

\begin{tabular}{|c|c|c|c|c|}
\hline & FQ = QUALITY & 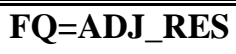 & FQ=FITQUALITY $_{1}$ & FQ=FITQUALITY 2 \\
\hline VARIABLE & $\begin{array}{l}\text { Coefficient } \\
\text { (t-statistic) }\end{array}$ & $\begin{array}{l}\text { Coefficient } \\
\text { (t-statistic) }\end{array}$ & $\begin{array}{l}\text { Coefficient } \\
\text { (t-statistic) }\end{array}$ & $\begin{array}{l}\text { Coefficient } \\
\text { (t-statistic) }\end{array}$ \\
\hline BETA & $\begin{array}{c}0.0042 \\
(2.26)^{* *}\end{array}$ & $\begin{array}{c}0.0039 \\
(2.15)^{* *}\end{array}$ & $\begin{array}{c}0.0036 \\
(2.05)^{* *}\end{array}$ & $\begin{array}{l}0.0035 \\
(1.92)^{*}\end{array}$ \\
\hline SIZE & $\begin{array}{c}-0.0390 \\
(-12.01)^{* * *}\end{array}$ & $\begin{array}{c}-0.0390 \\
(-11.65)^{* * *}\end{array}$ & $\begin{array}{l}-0.0370 \\
(-14.66)\end{array}$ & $\begin{array}{c}-0.0370 \\
(-14.73)^{* * *}\end{array}$ \\
\hline B_M & $\begin{array}{c}0.0216 \\
(9.16)^{* * *}\end{array}$ & $\begin{array}{c}0.0216 \\
(8.85)^{* * *}\end{array}$ & $\begin{array}{c}0.0200 \\
(9.59)^{* * *}\end{array}$ & $\begin{array}{c}0.0202 \\
(10.06)^{* * *}\end{array}$ \\
\hline LEVERAGE & $\begin{array}{c}0.0466 \\
(6.61)^{* * *} \\
\end{array}$ & $\begin{array}{c}0.0492 \\
(6.56)^{* * *} \\
\end{array}$ & $\begin{array}{c}0.0416 \\
(5.83)^{* * *}\end{array}$ & $\begin{array}{c}0.0433 \\
(6.26)^{* * *} \\
\end{array}$ \\
\hline E_GROWTH & $\begin{array}{c}0.0159 \\
(5.76)^{* * *}\end{array}$ & $\begin{array}{c}0.0157 \\
(5.88)^{* * *} \\
\end{array}$ & $\begin{array}{c}0.0160 \\
(5.91)^{* * *}\end{array}$ & $\begin{array}{c}0.0164 \\
(5.85)^{* * *} \\
\end{array}$ \\
\hline QUALITY & $\begin{array}{c}-0.0035 \\
(-2.62)^{* *}\end{array}$ & & & \\
\hline ADJ_RES & & $\begin{array}{c}0.1037 \\
(2.77)^{* *}\end{array}$ & & \\
\hline FITQUALITY $_{1}$ & & & $\begin{array}{l}-0.030 \\
(-0.17) \\
\end{array}$ & \\
\hline FITQUALITY $_{2}$ & & & & $\begin{array}{c}0.0341 \\
(0.32)\end{array}$ \\
\hline Mean Adj. $\mathrm{R}^{2}$ & 0.2756 & 0.2757 & 0.2720 & 0.2725 \\
\hline
\end{tabular}

***, **, * Statistical significance at the 1\%, 5\%, 10\% level (two-tailed test). The t-statistics are reported in parentheses.

$\mathrm{RES}_{\mathrm{i}, \mathrm{t}}$ is equal to the absolute value of the residuals obtained from the following industry regression estimated for each year $\mathrm{t}$ for each two-digit SIC code:

$\mathrm{CFO}_{\mathrm{i}, \mathrm{t}+1}=\alpha_{0}+\beta_{1} \mathrm{CFO}_{\mathrm{i}, \mathrm{t}}+\beta_{2} \Delta \mathrm{AR}_{\mathrm{i}, \mathrm{t}}+\beta_{3} \Delta \mathrm{INV}_{\mathrm{i}, \mathrm{t}}+\beta_{4} \Delta \mathrm{AP}_{\mathrm{i}, \mathrm{t}}+\beta_{5} \mathrm{DEPR}_{\mathrm{i}, \mathrm{t}}+\beta_{6} \mathrm{OTHER}_{\mathrm{i}, \mathrm{t}}+\varepsilon_{\mathrm{i}, \mathrm{t}+1}$

$\mathrm{FQ}_{\mathrm{i}, \mathrm{t}}$ - Financial reporting quality measure:

QUALITY: Indicator variable equal to one if $\mathrm{RES}_{\mathrm{i}, \mathrm{t}}<$ industry median RES.

ADJ_RES: Industry-adjusted $\mathrm{RES}_{\mathrm{i}, \mathrm{t}}$.

FITQUALITY $_{1}$ : Instrumental variable which is equal to the fitted probabilities obtained from a Probit estimation, where the dependent variable is QUALITY.

FITQUALITY $_{2}$ : Instrumental variable which is equal to the fitted value obtained from an OLS regression, where the dependent variable is ADJ_RES.

Table 8 reports mean coefficients and corresponding t-statistics (corrected for serial-correlation) from yearly OLS regressions. This table is similar to Table 6 except that the implied cost of capital is estimated using the stock price as of January instead of July $1^{\text {st }}$. As in Table 6, the implied cost of capital is computed using analyst forecasts as of June. 
Table 9

Consequences of Financial Reporting Quality: Association between Bid-Ask Spreads and Reporting Quality

$$
\operatorname{SPREAD}_{i, t}=\chi_{0}+\chi_{1} \operatorname{SIZE}_{i, t}+\chi_{2} \operatorname{VOLUME}_{i, t}+\chi_{3} \operatorname{STDRET}_{i, t}+\chi_{4} \operatorname{LIST}_{i, t}+\chi_{5} \mathrm{FQ}_{i, t}+\zeta_{i, t}
$$

\begin{tabular}{|c|c|c|c|c|}
\hline & FQ = QUALITY & $\begin{array}{l}\text { FQ=ADJ_RES } \\
\end{array}$ & $\overline{F_{\text {FQ}}=\mathrm{FITQUALITY}_{1}}$ & $\overline{\text { FQ=FITQUALITY }}$ \\
\hline VARIABLE & $\begin{array}{l}\text { Coefficient } \\
\text { (t-statistic) }\end{array}$ & $\begin{array}{l}\text { Coefficient } \\
\text { (t-statistic) }\end{array}$ & $\begin{array}{l}\text { Coefficient } \\
\text { (t-statistic) }\end{array}$ & $\begin{array}{l}\text { Coefficient } \\
\text { (t-statistic) }\end{array}$ \\
\hline SIZE & $\begin{array}{c}-0.0170 \\
(-10.16)^{* * *}\end{array}$ & $\begin{array}{c}-0.0160 \\
(-10.25)^{* * *}\end{array}$ & $\begin{array}{c}-0.0150 \\
(-9.88)^{* * *}\end{array}$ & $\begin{array}{c}-0.0010 \\
(-10.46)^{* * *}\end{array}$ \\
\hline VOLUME & $\begin{array}{c}-0.020 \\
(-7.55) * * *\end{array}$ & $\begin{array}{c}-0.020 \\
(-7.82)^{* * *}\end{array}$ & $\begin{array}{c}-0.018 \\
(-5.67)^{* * *}\end{array}$ & $\begin{array}{c}-0.019 \\
(-6.04)^{* * *}\end{array}$ \\
\hline STDRET & $\begin{array}{c}0.0969 \\
(12.60)^{* * *}\end{array}$ & $\begin{array}{c}0.0956 \\
(12.10)^{* * *}\end{array}$ & $\begin{array}{c}0.0918 \\
(10.62)^{* * *}\end{array}$ & $\begin{array}{c}0.0903 \\
(12.14)^{* * *}\end{array}$ \\
\hline LIST & $\begin{array}{l}0.0025 \\
(0.76) \\
\end{array}$ & $\begin{array}{l}0.0019 \\
(0.58) \\
\end{array}$ & $\begin{array}{l}-0.0003 \\
(-0.11) \\
\end{array}$ & $\begin{array}{c}-0.001 \\
(-0.39)^{* * *} \\
\end{array}$ \\
\hline QUALITY & $\begin{array}{l}-0.0027 \\
(-1.51)\end{array}$ & & & \\
\hline ADJ_RES & & $\begin{array}{c}0.0699 \\
(4.25)^{* * *} \\
\end{array}$ & & \\
\hline FITQUALITY $_{1}$ & & & $\begin{array}{c}-0.0778 \\
(-2.15)^{* *}\end{array}$ & \\
\hline FITQUALITY $_{2}$ & & & & $\begin{array}{c}0.407 \\
(4.61)^{* * *}\end{array}$ \\
\hline Mean Adj. $\mathbf{~}^{2}$ & 0.3312 & 0.3215 & 0.3344 & 0.3405 \\
\hline
\end{tabular}

$* * *, * *, *$ Statistical significance at the $1 \%, 5 \%, 10 \%$ level (two-tailed test). The t-statistics are reported in parentheses.

$\mathrm{RES}_{\mathrm{i}, \mathrm{t}}$ is equal to the absolute value of the residuals obtained from the following industry regression estimated for each year $t$ for each two-digit SIC code:

$\mathrm{CFO}_{\mathrm{i}, \mathrm{t}+1}=\alpha_{0}+\beta_{1} \mathrm{CFO}_{\mathrm{i}, \mathrm{t}}+\beta_{2} \Delta \mathrm{AR}_{\mathrm{i}, \mathrm{t}}+\beta_{3} \Delta \mathrm{INV}_{\mathrm{i}, \mathrm{t}}+\beta_{4} \Delta \mathrm{AP}_{\mathrm{i}, \mathrm{t}}+\beta_{5} \mathrm{DEPR}_{\mathrm{i}, \mathrm{t}}+\beta_{6} \mathrm{OTHER}_{\mathrm{i}, \mathrm{t}}+\varepsilon_{\mathrm{i}, \mathrm{t}+1}$

$\mathrm{FQ}_{\mathrm{i}, \mathrm{t}}-$ Financial reporting quality measure:

QUALITY: Indicator variable equal to one if $\mathrm{RES}_{\mathrm{i}, \mathrm{t}}<$ industry median RES.

ADJ_RES: Industry-adjusted $\mathrm{RES}_{\mathrm{i}, \mathrm{t}}$.

FITQUALITY $_{1}$ : Instrumental variable which is equal to the fitted probabilities obtained from a Probit estimation, where the dependent variable is QUALITY.

FITQUALITY $_{2}$ : Instrumental variable which is equal to the fitted value obtained from an OLS regression, where the dependent variable is ADJ_RES.

Table 9 reports mean coefficients and corresponding t-statistics (corrected for serial-correlation) from yearly OLS regressions. 
Table 10

\section{Consequences of Financial Reporting Quality: Association between Analyst Forecast Dispersion and Reporting Quality}

$$
\operatorname{DISP}_{i, t}=\lambda_{0}+\lambda_{1} \operatorname{SIZE}_{i, t}+\lambda_{2} \operatorname{SURP}_{i, t}+\lambda_{3} \operatorname{ANALYST}_{i, t}+\lambda_{4} F Q_{i, t}+\pi_{i, t}
$$

\begin{tabular}{|c|c|c|c|c|}
\hline & $\overline{F Q}$ FQ QUALITY & $\bar{~} \overline{\text { FQ=ADJ_RES }}$ & 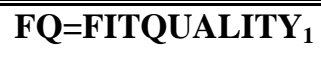 & $\overline{\text { FQ=FITQUALITY }}$ \\
\hline VARIABLE & $\begin{array}{l}\text { Coefficient } \\
\text { (t-statistic) }\end{array}$ & $\begin{array}{l}\text { Coefficient } \\
\text { (t-statistic) }\end{array}$ & $\begin{array}{l}\text { Coefficient } \\
\text { (t-statistic) }\end{array}$ & $\begin{array}{l}\text { Coefficient } \\
\text { (t-statistic) }\end{array}$ \\
\hline SIZE & $\begin{array}{c}-0.00007 \\
(-8.87) * * *\end{array}$ & $\begin{array}{c}-0.00007 \\
(-9.27)^{* * *}\end{array}$ & $\begin{array}{c}-0.00006 \\
(-1.75)\end{array}$ & $\begin{array}{c}-0.00004 \\
(-1.41)\end{array}$ \\
\hline SURP & $\begin{array}{c}0.0279 \\
(3.19)^{* * *}\end{array}$ & $\begin{array}{c}0.0281 \\
(3.29)^{* * *}\end{array}$ & $\begin{array}{c}0.0030 \\
(3.88)^{* * *}\end{array}$ & $\begin{array}{c}0.0031 \\
(3.99)^{* * *}\end{array}$ \\
\hline ANALYST & $\begin{array}{c}-0.003 \\
(-4.99) * * *\end{array}$ & $\begin{array}{c}-0.003 \\
(-3.97)^{* * *}\end{array}$ & $\begin{array}{c}-0.0023 \\
(-3.77)^{* * *}\end{array}$ & $\begin{array}{c}-0.0021 \\
(-3.52)^{* * *}\end{array}$ \\
\hline QUALITY & $\begin{array}{c}-0.0429 \\
(-4.33) * * *\end{array}$ & & & \\
\hline ADJ_RES & & $\begin{array}{c}0.8636 \\
(2.39)^{* *}\end{array}$ & & \\
\hline FITQUALITY $_{1}$ & & & $\begin{array}{c}-0.1156 \\
(-3.11)^{* * *}\end{array}$ & \\
\hline FIRQUALITY $_{2}$ & & & & $\begin{array}{c}0.1552 \\
(2.53)^{* *}\end{array}$ \\
\hline Mean Adj. $\mathbf{R}^{2}$ & 0.0981 & 0.0891 & 0.0860 & 0.0810 \\
\hline
\end{tabular}

$* * *, * *, *$ Statistical significance at the $1 \%, 5 \%, 10 \%$ level (two-tailed test). The t-statistics are reported in parentheses.

$\mathrm{RES}_{\mathrm{i}, \mathrm{t}}$ is equal to the absolute value of the residuals obtained from the following industry regression estimated for each year $t$ for each two-digit SIC code:

$\mathrm{CFO}_{\mathrm{i}, \mathrm{t}+1}=\alpha_{0}+\beta_{1} \mathrm{CFO}_{\mathrm{i}, \mathrm{t}}+\beta_{2} \Delta \mathrm{AR}_{\mathrm{i}, \mathrm{t}}+\beta_{3} \Delta \mathrm{INV}_{\mathrm{i}, \mathrm{t}}+\beta_{4} \Delta \mathrm{AP}_{\mathrm{i}, \mathrm{t}}+\beta_{5} \mathrm{DEPR}_{\mathrm{i}, \mathrm{t}}+\beta_{6} \mathrm{OTHER}_{\mathrm{i}, \mathrm{t}}+\varepsilon_{\mathrm{i}, \mathrm{t}+1}$

$\mathrm{FQ}_{\mathrm{i}, \mathrm{t}}$ - Financial reporting quality measure:

QUALITY: Indicator variable equal to one if $\mathrm{RES}_{\mathrm{i}, \mathrm{t}}<$ industry median RES.

ADJ_RES: Industry-adjusted $\mathrm{RES}_{\mathrm{i}, \mathrm{t}}$.

FITQUALITY $_{1}$ : Instrumental variable which is equal to the fitted probabilities obtained from a Probit estimation, where the dependent variable is QUALITY.

FITQUALITY $_{2}$ : Instrumental variable which is equal to the fitted value obtained from an OLS regression, where the dependent variable is ADJ_RES.

Table 10 reports mean coefficients and corresponding t-statistics (corrected for serial-correlation) from yearly OLS regressions. 


\section{Table 11}

\section{Consequences of Financial Reporting Quality: Association between Analyst Following and Reporting Quality}

$$
\operatorname{ANALYST}_{i, t}=\varpi_{0}+\varpi_{1} S I Z E_{i, t}+\varpi_{2} \mathrm{EPS}_{i, t}+\varpi_{3} \mathrm{ROA}_{i, t}+\varpi_{4} \mathrm{GROWTH}_{i, t}+\varpi_{5} \mathrm{FQ}_{i, t}+\psi_{i, t}
$$

\begin{tabular}{|c|c|c|c|c|}
\hline & FQ = QUALITY & FQ=ADJ_RES & $\overline{F Q=F I T Q U A L I T Y ~} 1$ & $\overline{F Q=F I T Q U A L I T Y ~} 2$ \\
\hline VARIABLE & $\begin{array}{l}\text { Coefficient } \\
\text { (t-statistic) }\end{array}$ & $\begin{array}{l}\text { Coefficient } \\
\text { (t-statistic) }\end{array}$ & $\begin{array}{l}\text { Coefficient } \\
\text { (t-statistic) }\end{array}$ & $\begin{array}{l}\text { Coefficient } \\
\text { (t-statistic) }\end{array}$ \\
\hline SIZE & $\begin{array}{c}0.4078 \\
(33.66)^{* * *}\end{array}$ & $\begin{array}{c}0.4060 \\
(33.67)^{* * *}\end{array}$ & $\begin{array}{c}0.4124 \\
(30.36)^{* * *}\end{array}$ & $\begin{array}{c}0.4143 \\
(32.37)^{* * *}\end{array}$ \\
\hline EPS & $\begin{array}{c}-0.046 \\
(-4.71)^{* * *}\end{array}$ & $\begin{array}{c}-0.048 \\
(-5.15)^{* * *}\end{array}$ & $\begin{array}{c}-0.053 \\
(-5.41)^{* * *}\end{array}$ & $\begin{array}{c}-0.059 \\
(-5.92)^{* * *}\end{array}$ \\
\hline ROA & $\begin{array}{c}0.2655 \\
(2.91)^{* *}\end{array}$ & $\begin{array}{c}0.4209 \\
(3.84)^{* * *}\end{array}$ & $\begin{array}{c}0.4128 \\
(7.82)^{* * *}\end{array}$ & $\begin{array}{c}0.759 \\
(5.65)^{* * *}\end{array}$ \\
\hline GROWTH & $\begin{array}{c}0.1199 \\
(3.67)^{* * *}\end{array}$ & $\begin{array}{c}0.1272 \\
(3.74)^{* * *}\end{array}$ & $\begin{array}{c}0.1723 \\
(4.14)^{* * *}\end{array}$ & $\begin{array}{c}0.1308 \\
(3.85)^{* * *}\end{array}$ \\
\hline QUALITY & $\begin{array}{c}0.0052 \\
(0.40)\end{array}$ & & & \\
\hline ADJ_RES & & $\begin{array}{c}-0.965 \\
(-2.76)^{* *} \\
\end{array}$ & & \\
\hline FITQUALITY $_{1}$ & & & $\begin{array}{c}0.6119 \\
(2.73)^{* *}\end{array}$ & \\
\hline FITQUALITY $_{2}$ & & & & $\begin{array}{c}-6.474 \\
(-3.62) * * *\end{array}$ \\
\hline Mean Adj. $\mathrm{R}^{2}$ & 0.3325 & 0.3421 & 0.3655 & 0.3522 \\
\hline
\end{tabular}

***, **, * Statistical significance at the $1 \%, 5 \%, 10 \%$ level (two-tailed test). The t-statistics are reported in parentheses.

$\mathrm{RES}_{\mathrm{i}, \mathrm{t}}$ is equal to the absolute value of the residuals obtained from the following industry regression estimated for each year $\mathrm{t}$ for each two-digit SIC code:

$\mathrm{CFO}_{\mathrm{i}, \mathrm{t}+1}=\alpha_{0}+\beta_{1} \mathrm{CFO}_{\mathrm{i}, \mathrm{t}}+\beta_{2} \Delta \mathrm{AR}_{\mathrm{i}, \mathrm{t}}+\beta_{3} \Delta \mathrm{INV}_{\mathrm{i}, \mathrm{t}}+\beta_{4} \Delta \mathrm{AP}_{\mathrm{i}, \mathrm{t}}+\beta_{5} \mathrm{DEPR}_{\mathrm{i}, \mathrm{t}}+\beta_{6} \mathrm{OTHER}_{\mathrm{i}, \mathrm{t}}+\varepsilon_{\mathrm{i}, \mathrm{t}+1}$

$\mathrm{FQ}_{\mathrm{i}, \mathrm{t}}-$ Financial reporting quality measure:

QUALITY: Indicator variable equal to one if $\mathrm{RES}_{\mathrm{i}, \mathrm{t}}<$ industry median RES.

ADJ_RES: Industry-adjusted $\mathrm{RES}_{\mathrm{i}, \mathrm{t}}$.

FITQUALITY $_{1}$ : Instrumental variable which is equal to the fitted probabilities obtained from a Probit estimation, where the dependent variable is QUALITY.

FITQUALITY $_{2}$ : Instrumental variable which is equal to the fitted value obtained from an OLS regression, where the dependent variable is ADJ_RES.

Table 11 reports mean coefficients and corresponding t-statistics (corrected for serial-correlation) from yearly OLS regressions. 


\section{References}

Admati, A. and P. Pfleiderer. 2000. Forcing Firms to Talk: Financial Disclosure Regulation and Externalities. The Review of Financial Studies 13: 479-519.

Amihud, Y. and H. Mendelson. 1986. Asset Pricing and the Bid-Ask Spread. Journal of Financial Economics 17: 223-249.

Baiman, S. and R.E. Verrecchia. 1996. The Relation among Capital Markets, Financial Disclosure, Production Efficiency and Insider Trading. Journal of Accounting Research 34: 1-22.

Barone, G. 2002. Perceptions of Earnings Quality and their Association with the Cost of Equity Capital. Working Paper, University of Texas at Austin.

Barnow, B., G. Cain, and A. Goldberger. 1980. Issues in the Analysis of Selectivity Bias. In Evaluation Studies Review Annual, edited by E. Stromsdorfer and G. Farkash. Beverly Hills, CA: Sage Publication.

Barry, C. and S. Brown. 1985. Differential Information and Security Market Equilibrium. Journal of Financial and Quantitative Analysis: 407-422.

Barth, M., D.P. Cram, and K. Nelson. 2001. Accruals and the Prediction of Future Cash Flows. The Accounting Review 76: 27-58.

Barth, M. and W. Landsman. 2003. Cost of Capital and Quality of Financial Statement Information. Working Paper, Stanford University.

Bhattacharya, U., H. Daouk, and M. Welker. 2003. The World Pricing of Earnings Opacity. The Accounting Review 78: 641-678.

Belsley , D., E. Kuh, and R. Welsch., ed. 1980. Regression Diagnostics: Identifying Influential Data and Sources of Collinearity. New York, John Wiley and Sons.

Bernard, V. 1995. The Feltham-Ohlson Framework: Implications for Empiricists. Contemporary Accounting Research 11: 733-747.

Bhushan, R. 1989. Firm Characteristics and Analyst Following. Journal of Accounting and Economics 11: 255-274.

Botosan, C. 1997. Disclosure Level and the Cost of Equity Capital. The Accounting Review 72: 323-349.

Botosan, C. and M. Harris. 2000. Motivations for a Change in Disclosure Frequency and its Consequences: An Examination of Voluntary Quarterly Segment Disclosures. Journal of Accounting Research 38: 329-353. 
Botosan, C.A., and M. Plumlee. 2002. A Re-examination of Disclosure Level and the Expected Cost of Equity Capital. Journal of Accounting Research 40: 21-40.

Butler M., A. G. Kraft and I. Weiss. 2002. The Effect of Reporting Frequency on the Timeliness of Earnings: The Cases of Voluntary and Mandatory Interim Reports. Working Paper, Columbia University.

Clarkson, P., J.Guedes, and R. Thompson. 1996. On the Diversification, Observability, and Measurement of Estimation Risk. Journal of Financial and Quantitative Analysis: 69-84.

Clarkson, P., J.L. Kao and G. Richardson. 1994. The Voluntary Inclusion of Forecasts in the MD\&A Section of Annual Reports. Contemporary Accounting Research 11: 423-450.

Coller, M. and T. Yohn. 1997. Management Forecast and Information asymmetry: An Examination of Bid-Ask Spreads. Journal of Accounting Research 35: 181-191.

Copeland, T. and D. Galai. 1983. Information Effects on the Bid-Ask Spread. The Journal of Finance 36: 1457-1469.

Core, J. 2001. A Review of the Empirical Disclosure Literature: Discussion. Journal of Accounting and Economics 31: 441-456.

Darrough, M., and N. Stoughton. 1990. Financial Disclosure Policy in an Entry Game. Journal of Accounting and Economics 12: 219-243.

Dechow, P. 1994. Accounting Earnings and Cash Flows as Measures of Firm Performance: The Role of Accounting Accruals. Journal of Accounting and Economics 18 : 3-42.

Dechow P. and Dichev I. 2002. The Quality of Accruals and Earnings: The Role of Accrual Estimation Errors. The Accounting Review 77 (Supplement): 35-59.

Dechow, P., S.P. Kothari, and R. Watts. 1998. The Relation between Earnings and Cash Flows. Journal of Accounting and Economics 25: 133-168.

Diamond D. and R. Verrecchia. 1991. Disclosure, Liquidity, and the Cost of Capital. The Journal of Finance 66: 1325-1355.

Dye, R.A. 1985a. Disclosure of Nonproprietary Information. Journal of Accounting Research 23: 123-145.

Dye, R.A. 1985b. Strategic Accounting Choice and the Effects of Alternative Financial Reporting Requirements. Journal of Accounting Research 23: 544-574. 
Dye, R.A. 1986. Proprietary and Nonproprietary Disclosures. Journal of Business 59 331-366.

Dye, R.A. 2001. An Evaluation of "Essays on Disclosure" and the Disclosure Literature in Accounting. Journal of Accounting and Economics 32 : 181-235.

Easley, D. and M. O’Hara. 2003. Information and the Cost of Capital. Forthcoming, The Journal of Finance.

Easley, D., S. Hvidkjaer, and M. O’Hara. 2002. Is Information Risk a Determinant of Assets Returns? Journal of Finance 57: 2185-2221.

Fama, E.F. and K. French. 1992. The Cross-Section of Expected Stock Returns. Journal of Finance 47: 427-465.

Fama, E.F. and K. French. 1993. Common Risk Factors in the Returns on Stocks and Bonds. Journal of Financial Economics 33: 3-56.

Fama, E.F. and K. French. 1996. Multifactor Explanations of Asset Pricing Anomalies. Journal of Finance 51: 55-84.

Fama, E.F. and K. French. 1997. Industry Costs of Equity. Journal of Financial Economics 43: 153-193.

Fama, E.F. and J. MacBeth. 1973. Risk, Return and Equilibrium: Empirical Tests. Journal of Political Economy 81: 607-636.

Fairfield, P., R. Sweeney, and T. Yohn. 1996. Accounting Classification and the Predictive Content of Earnings. The Accounting Review 71: 337-355.

Fields T. D., T. Z. Lys, and L. Vincent. 2001. Empirical Research on Accounting Choice. Journal of Accounting and Economics 31: 255-307.

Financial Accounting Standards Board. 1978. Statement of Financial Accounting Concepts Number 1, Objectives of Financial Reporting by Business Enterprises. New York, NY. FASB.

Finger, C. 1994. The Ability of Earnings to Predict Future Earnings and Cash Flow. Journal of Accounting Research 32: 210-223.

Francis, J., R. LaFond, P. Olsson, and K. Schipper. 2003a. Cost of Capital and Earnings Attributes. Working Paper, Duke University.

Francis, J., R. LaFond, P. Olsson, and K. Schipper. 2003b. The Market Pricing of Accruals Quality. Working Paper, Duke University. 
Gigler, F. 1994. Self-Enforcing Voluntary Disclosures. Journal of Accounting Research 32: 224-240.

Gode, D. and P. Mohanram. 2002. Inferring the Cost of Capital Using the OhlsonJuettner Model. Working Paper, New York University.

Glosten, L. and P. Milgrom 1985. Bid Ask and Transaction Prices in a Specialist Market with Heterogeneously Informed Traders. Journal of Financial Economics: 71100.

Guay, W., S.P. Kothari, and S. Shu. 2003. An Empirical Assessment of Cost of Capital Measures. Working Paper, University of Pennsylvania.

Greene, W.H. ed. 2000. Econometric Analysis. Upper Saddle River, NJ: Prentice Hall.

Harris, M.S. 1998. The Association between Competition and Managers' Business Segment Reporting Decisions. Journal of Accounting Research 36: 111-128.

Hayes, R. and R. Lundholm.1996. Segment Reporting to the Capital Market in the Presence of a Competitor. Journal of Accounting Research 34: 261-279.

Healy, P. M. and K.G. Palepu. 2001. Information Asymmetry, Corporate disclosure, and the Capital markets: A Review of the Empirical Disclosure Literature. Journal of Accounting and Economics 31: 405-440.

Healy, P., A. Hutton, and K. Palepu. 1999. Stock Performance and Intermediation Changes Surrounding Sustained Increases in Disclosure. Contemporary Accounting Research 16: 485-520.

Heckman, J. 1979. Sample Selection Bias as Specification Error. Econometrica 46: 1251-1271.

Holthausen, R. and R.E. Verrecchia. 1988. The Effect of Sequential Information Releases on the Variance of Price Changes in an Intertemporal Multi-Asset Market. Journal of Accounting Research 26: 82-106.

Hribar, P. and D.A. Colllins. 2002. Errors in Estimating Accruals: Implications for Empirical Research. Journal of Accounting Research 40: 105-135.

Jensen, M. and W.H. Meckling. 1976. The Theory of the Firm: Managerial Behavior, Agency Costs and Ownership Structure. Journal of Financial Economics 3: 305360.

Kim, O. and R.E. Verrecchia. 1991. Trading Volume and Price Reactions to Public Announcements. Journal of Accounting Research 29: 302-321. 
Lang, M., and R. Lundholm. 1993. Cross-sectional Determinants of Analyst Ratings of Corporate Disclosures. Journal of Accounting Research 31: 246-271.

Lang, M., and R. Lundholm. 1996. Corporate Disclosure Policy and Analyst Behavior. The Accounting Review 71: 467-492.

La Porta, R. 1996. Expectations and the Cross-Section of Stock Returns. Journal of Finance 51: 1715-1742.

Lee, C., B. Mucklow, and M. Ready. 1993. Spreads, Depths and the Impact of Earnings Information: An Intraday Analysis. The Review of Financial Studies 6: 345-374.

Leftwich, R.W., R. L. Watts, and J.L. Zimmerman. 1981. Voluntary Corporate Disclosure: The Case of Interim Reporting. Journal of Accounting Research 18: 50-77.

Leuz, C. and R. Verrecchia. 2000. The Economic Consequences of Increased Disclosure. Journal of Accounting Research 38 (Supplement): 91-124.

Lys, Z. T. and S. Sohn. 1990. The Association between Revisions of Financial Analysts' Earnings Forecasts and Security-Price Changes. Journal of Accounting and Economics 13: 341-363.

Maddala, G.S. ed. 1983. Limited-Dependent and Qualitative Variables in Econometrics. New York, NY: Cambridge University Press.

Mikhail, M., B. Walther, and R. Willis. 2003. Reactions to Dividend Changes Conditional on Earnings Quality. Journal of Accounting, Auditing and Finance 18: 121-151.

Newman, P. and R. Sansing. 1993. Disclosure Policies with Multiple Users. Journal of Accounting Research 31: 92-112.

Ohlson, J.A. and B.E. Juettner-Nauroth. 2000. Expected EPS and EPS Growth as Determinants of Value. Working paper, New York University.

Penman, S. ed. 2001. Financial Statement Analysis \& Security Valuation. McGrawHill Irwin, New York, NY.

Penman, S. and X. Zhang. 2002. Accounting Conservatism, the Quality of Earnings and Stock Returns. The Accounting Review 77: 237-265.

Piotroski, J. 2003. Segment Reporting Fineness and the Precision of Investors Beliefs. Working Paper, University of Chicago. 
Pownall, G., C. Wasley, and G. Waymire. 1993. The Stock Price Effects of Alternative Types of Management Earnings Forecasts. The Accounting Review 68: 896-912.

Richardson, S., R. Sloan, M. Soliman, and I. Tuna. 2002. Information in Accruals about the Quality of Earnings. Working Paper, University of Michigan.

Scott, T.W. 1994. Incentives and Disincentives for Financial Disclosure: Voluntary Disclosure of Defined Benefit Pension Plan Information by Canadian Firms. The Accounting Review 69: 26-43.

Sengupta, P. 1998. Corporate Disclosure Quality and the Cost of Debt. The Accounting Review 73: 459-474.

Shin, Y. 2001. The Effect of Product Market Competition on Corporate Voluntary Disclosure Decisions. Working paper, Tulane University.

Verrecchia, R.E. 1983. Discretionary Disclosure. Journal of Accounting and Economics 5: 179-195.

Verrecchia, R.E. 1990a. Endogenous Proprietary Costs Through Firm Interdependence. Journal of Accounting and Economics 12: 245-251.

Verrecchia, R.E. 1990b. Information Quality and Discretionary Disclosure. Journal of Accounting and Economics 12: 365-380.

Verrecchia, R.E. 2001. Essays on Disclosure. Journal of Accounting and Economics 32: 97-180.

Wagenhofer, A. 1990. Voluntary Disclosure with a Strategic Opponent. Journal of Accounting and Economics 12: 341-363.

Warfield, T., J. Wild, and K. Wild. 1995. Managerial Ownership, Accounting Choices, and Informativeness of Earnings. Journal of Accounting and Economics 20:61-91.

Watts, R.L. and J.L. Zimmerman., ed. 1986. Positive Accounting Theory. Prentice Hall, Englewood Cliff NJ.

Welker, M. 1995. Disclosure Policy, Information Asymmetry and Liquidity in Equity Markets. Contemporary Accounting Research 11: 801-828.

Wooldridge, J.M., ed. 2002. Econometric Analysis of Cross Section and Panel Data. The MIT Press, Cambridge Massachusetts. 